\title{
Clarence Cameron White: Classical Violin Performance and Pedagogy in the African American Community
}

\author{
Alexandra Kori Hill
}

Follow this and additional works at: https://researchrepository.wvu.edu/etd

\section{Recommended Citation}

Hill, Alexandra Kori, "Clarence Cameron White: Classical Violin Performance and Pedagogy in the African American Community" (2015). Graduate Theses, Dissertations, and Problem Reports. 5802.

https://researchrepository.wvu.edu/etd/5802

This Thesis is protected by copyright and/or related rights. It has been brought to you by the The Research Repository @ WVU with permission from the rights-holder(s). You are free to use this Thesis in any way that is permitted by the copyright and related rights legislation that applies to your use. For other uses you must obtain permission from the rights-holder(s) directly, unless additional rights are indicated by a Creative Commons license in the record and/ or on the work itself. This Thesis has been accepted for inclusion in WVU Graduate Theses, Dissertations, and Problem Reports collection by an authorized administrator of The Research Repository @ WVU. For more information, please contact researchrepository@mail.wvu.edu. 


\title{
Clarence Cameron White:
}

Classical Violin Performance and Pedagogy in the African American Community

\section{By}

\author{
Alexandra Kori Hill \\ Thesis submitted \\ to the College of Creative Arts \\ at West Virginia University
}

in partial fulfillment of the requirements for the degree of

Master of Music in

Musicology

\begin{abstract}
Travis Stimeling, Ph.D., Chair
Evan MacCarthy, Ph.D.

Paul Scea
\end{abstract}

School of Music

Morgantown, West Virginia

2015

Keywords: Clarence Cameron White, African Americans, Classical Violin Copyright 2015 Alexandra Kori Hill 


\title{
Abstract \\ Clarence Cameron White: \\ Classical Violin and Pedagogy in the African American Community
}

\begin{abstract}
Alexandra Kori Hill
This thesis focuses on the performing and teaching career of the African American classical violinist, Clarence Cameron White. Discussions of recital programming, reviews, pedagogical articles and musical essays written by White will provide a look into African Americans' presence and involvement within classical violin performance and instruction. The racial and cultural signifiers that are tightly woven with many styles and genres in American music have also been applied to Western art music and classical violin, requiring a discussion of racial and cultural stereotypes in American society.
\end{abstract}




\section{Table of Contents}

“There's More of Us?": How This Thesis Came To Be

p. $\mathbf{i}$

Introduction: Exposure \& Limitations

p. $\mathbf{x}$

Chapter One:

“I Definitely Made Up My Mind To Be A Violinist": Education \& Connections

p. 1

Chapter Two:

White's Pedagogy in The Negro Music Journal

p. 16

Chapter Three:

"One of the greatest players we have heard": Reviews and Repertoire

p. 33

Chapter Four:

To Be A Classical Violinist and Black: Western art music as a cultural and racial signifier

p. 48

Conclusion

p. 60

Bibliography

p. 63 


\section{"There's More of Us?": How This Thesis Came To Be}

In the spring of 1990, an article titled "Black String Musicians: Ascending the Scale" was published in the Black Music Research Journal. The author, Caldwell Titcomb, discusses the careers and recordings of several black classical string musicians who demonstrate great musical and technical abilities and who might lead to the long delayed recognition of black classical violinists, violists and cellists in the late twentieth century. Though Titcomb focuses on musicians active in the mid to late twentieth century, his observations may still be applied to the current narrative of classical music. Those African American musicians that have achieved mainstream success and inclusion in the narrative are either vocalists (i.e. Leontyne Price, Jessye Norman and Kathleen Battle, to name a few) or pianists such as André Watts. ${ }^{1}$ José White (18361918), Joseph Douglas (1871-1935), and Clarence Cameron White (1880-1960) were all black violinists active at some point in the nineteenth and early twentieth centuries, yet their names and those of other non-white instrumentalists within Western art music are still on the periphery of its history. ${ }^{2}$

As a black American violinist, I have witnessed this not only within the music history literature I read growing up but also as a member of a society where musical styles are often cultural identifiers. It was not uncommon for me to be one of a few (if not the only) black children in the violin group class, orchestra or chamber group. For many of my early years I assumed my sister and myself were the only African American children who played classical

${ }^{1}$ Eileen Southern, The Music of Black Americans: A History, $3^{\text {rd }}$ Edition [New York: W. W. Norton Company, Inc. 1997], 529-535.

${ }^{2}$ Caldwell Titcomb, "Black String Musicians: Ascending the Scale," in Black Music Research Journal, 1990: 107. Southern, The Music of Black Americans, 524-525, 587-588. 
violin in our city. Even within the black community this was seen as an anomaly. The apparent absence of black string players of classical music did not stop me from playing but created the false idea that I was an exception to the rule.

However, I would soon learn that there were many scholars, performers and teachers taking steps to acknowledge black classical performers within the historical narrative and including violin repertoire by black classical composers for recordings and competitions. ${ }^{3}$ In elementary school I learned of the Sphinx Competition, a national competition for Black and Latino string players based in Detroit Michigan and was founded in 1997 to showcase and increase the diversity within classical music. ${ }^{4}$ While working on "Mother and Child" from William Grant Still's Suite for Violin and Piano for the Sphinx Competition, my high school violin teacher introduced me to Rachel Barton Pine's recording Violin Concertos by Black Composers of the $18^{\text {th }}$ and $19^{\text {th }}$ Centuries. ${ }^{5}$ Through this recording, I was exposed to the lives of Samuel Coleridge-Taylor (1875-1912), José White, Chevalier de Saint-Georges (1745-1799) and Chevalier de Meude-Monpas. I would soon learn of more black classical violinist/composers, one of them Clarence Cameron White, whose composition "Levee Dance" was recorded by Jascha Heifetz. ${ }^{6}$ His career as a violinist, teacher and composer was outlined within Eileen

3 John Gray, Blacks in Classical Music: A Bibliographical Guide to Composers, Performers, and Ensembles [Westport: Greenwood Press, Inc. 1988].

${ }^{4}$ Sphinx Organization. http://sphinxmusic.org. (accessed March 30, 2015).

${ }^{5}$ Rachel Barton Pine, Violin Concertos by Black Composers of the $18^{\text {th }}$ and $19^{\text {th }}$ Centuries, CDR 90000 035.

${ }^{6}$ Jascha Heifetz, It Ain't Necessarily So: Legendary Classic and Jazz Studio Takes, Deutsche Grammophon 72444, 1944. 
Southern's The Music of Black Americans. ${ }^{7}$ It was exciting to read that people of African descent had played the violin within Western art music for hundreds of years. However, this information was not fully integrated into the main narrative of Western art music, at least in the books I had read growing up.

This project was inspired by my desire to see more black classical composers and violinists featured within this narrative. Even with the work of Eileen Southern's periodical The Black Perspective in Music, Columbia College's Black Music Research Journal, Rachel Barton Pine's recording and programing of music by women and black composers on her recitals and the recording of Samuel Coleridge-Taylor's violin concerto by Philippe Graffin, the history of black classical violinists and the study and performance of repertoire written by black composers is far from being a significant part of Western art music history and practice. ${ }^{8}$ Though a lot of Clarence Cameron White's career had been discussed and researched, the majority of it has been done within the history of black concert composers active in the Harlem Renaissance and use of black musical idioms within their works, such as White's opera Ouanga! ${ }^{9}$ While many scholars have written on his opera and provided detailed biographical information, his career as a violinist and violin teacher has yet to receive such treatment.

\footnotetext{
${ }^{7}$ Southern, The Music of Black Americans, 277-278.

${ }^{8}$ Philippe Graffin, Samuel Coleridge-Taylor and Antonin Dvorák: Violin Concertos, Avie Records
} AV0044, 2004. Lucius Wyatt, "The Inclusion of Concert Music of African-American Composers in Music History Courses" in Black Music Research Journal 16, no. 2 (Autumn 1996): 239-257. Dominique-René de Lerma, “Black Composers in Europe: A Works List" in Black Music Research Journal 10, no. 2 [Autumn 1990]: 275-334.

${ }^{9}$ Michael Largey, “Ouanga!": An African-American Opera About Haiti” in Lenox Avenue: A Journal of Interarts Inquiry 2 [1996]: 35-54. 
To understand why this part of his career and the careers of other black classical string players have not become a integral part of American musical memory, this paper will look at White's performing career and teaching positions within the social, cultural and political context of his life. This paper builds on the existing research of several scholars: Eileen Southern, whose book The Music of Black Americans presents a detailed chronological history of the music of African Americans. ${ }^{10}$ The Power of Black Music by Samuel A. Floyd Jr. analyzes the African musical styles, rituals and myths that influenced and remained within African American music, ${ }^{11}$ Racial Uplift and American Music, 1878-1943 by Lawrence Schenbeck explores how classical music in the black American community was sometimes interwoven with aspirations of racial uplift; Sinful Tunes and Spirituals: Black Folk Music To The Civil War by Dena J. Epstein provides written accounts of music making within black communities in the antebellum United States, ${ }^{12}$ and Lying Up A Nation: Race and Black Music by Ronald Radano analyses the development of racial concepts of musical sound and style within African American music and calls for a reformulation of the narrative of black American history to recognize its historical complexity. ${ }^{13}$ I am deeply indebted to their meticulous research and exposure to the enormous

${ }^{10}$ Southern, The Music of Black Americans, xix-xxii.

${ }^{11}$ Samuel A. Floyd, Jr., The Power of Black Music: Interpreting Its History From Africa To The United States \{New York: Oxford University Press, 1995], 5.

${ }^{12}$ Lawrence Schenbeck, Racial Uplift and American Music, 1878-1943 [Jackson: University Press of Mississippi, 2012], 3. Dena J. Epstein, Sinful Tunes and Spirituals: Black Folk Music To The Civil War [Urbana: University of Illinois Press, 2003], xxi.

${ }^{13}$ Ronald Radano, Lying Up A Nation: Race and Black Music [Chicago: The University of Chicago Press 2003], xii. 
amount of material that has been published on African American musical history and classical music.

This paper will be organized as follows:

- Introduction - Why are black American classical violinists not a part of the narrative of classical music in America? African Americans and other minorities are becoming more present in the narrative of American history and racism within its society and effects on its people are being recognized and discussed. ${ }^{14}$ However, the prejudice and biases about African Americans and African American culture may still be seen through micro-aggressions ("You don't know how to dance? But you're black! You don't like hip-hop music? But isn't that "your" music?") that limit public understanding of the varieties and evolutions that cultures go through. ${ }^{15}$ It is this limited view that have made African American musical culture synonymous with blues, jazz, R\&B, Motown, rap and hip-hop and European American musical culture with country music, bluegrass and Western art music.

- Chapter One - African Americans' exposure to European American musical styles and traditional instruments dates back to the first African slaves arriving to the Americas in $1619 .^{16}$

14 J. Blaine Hudson, "Simple Justice: Affirmative Action and American Racism in Historical Perspective" in The Black Scholar 25, no. 3 [Summer 1995]: 16-23. George Yancy and Noam Chomsky, "Noam Chomsky on the Roots of American Racism” in The New York Times [March 18, 2015] (accessed April 1, 2015).

15 Janice McCabe, "Racial and Gender Microaggressions on A Predominantly-White Campus: Experience of Black, Latina/o and White Undergraduates" in Race, Gender \& Class 16, no. 1/2 (2009): 134-135.

${ }^{16}$ Edward E. Baptist, The Half Has Never Been Told: Slavery and the Making of American Capitalism [New York: Basic Books, 2014], xiv. 
Musical adaptation and exchange are a part of the nation's history, yet many musical styles became and still are synonymous with cultural groups. To understand why this is, the history of spirituals and vocal music within the black community in nineteenth century America must be discussed and how vocal musical styles were and still are closely associated with black musical culture. While singing has a strong presence within African American musical styles and culture, it was not uncommon for African Americans to learn how to play traditional European instruments and musical styles. This will be demonstrated by looking at White's study of the violin under two prominent black violinists, Joseph Douglas and Will Marion Cook in the 1890s and at several musical institutions such as Oberlin College, Washington Conservatory of Music and Howard University that provided training in classical music to African Americans for voice and various instruments.

- Chapter Two - Clarence Cameron White's pedagogical approaches, how his instructors influenced his pedagogy and his career as a private teacher and university professor. Within an article by Nora Holt of the Chicago Defender, his Boston violin studio, established in 1911, is mentioned, in addition to the fact his studio consisted of white and black students, some of whom were acquiring public praise. ${ }^{17}$ Considering the narrative most commonly heard about white and black Americans, that of an adamantine racial divide, this is just one of many examples that challenge preconceived notions of social and economic interactions between black and white Americans during the periods of slavery and legal segregation. ${ }^{18}$ Yet this did not make his career

\footnotetext{
${ }^{17}$ Schenbeck, Racial Uplift, 88.

${ }^{18}$ Charles Wolfe, "Rural Black String Band Music" in Black Music Journal 10, no. 1 [Spring 1990]: 32-35.
} 
immune to racism, and the constant dual function of his success for himself and his race will be discussed.

- Chapter Three - This chapter will discuss Clarence Cameron White's performing career. Where were his recitals located? Did he play for mixed audiences, segregated audiences, or both kinds depending on the area of the country? Many black classical musicians were active within a limited sphere of influence, barred from complete integration due to the racism and even those within the mainstream were affected by biased musical expectations projected on African Americans. $^{19}$

White Americans' perspectives on Western art music as a European musical style will also be considered, with music critics such as John Sullivan Dwight heavily influencing Americans' ideas of "high" and "low- brow" music. ${ }^{20}$ Classical music originated in Europe, and was a fairly new addition to American musical culture and practice in the nineteenth century. This raises some interesting questions about why certain violinists have been cemented in classical music history and others have fallen into obscurity. Heifetz, Kreisler, Menuhin, Kogan, Szigeti and Oistrakh are members of the canon of violinists of the early to mid twentieth century, and will remain there for many years to come. Many American and African American violinists that enjoyed successful careers are not nearly as prevalent in the narrative of classical violin. This

\footnotetext{
${ }^{19}$ Melvin Fowler Foster, "The African-American Operatic Tenor: Coping with Discrimination” in Journal of Singing: the Official Journal of the National Association of Teachers of Singing 58, no. 3 [Jan-Feb 2002]: 203214.

${ }^{20}$ Joseph Horowitz, "Sermons in Tones": Sacralization as a Theme in American Classical Music" in American Music 16, no. 3 [Autumn, 1998]: 312-313.
} 
requires discussion of the possibility that they were seen as cultural representatives of Western art music since most (except Menuhin) were originally from European countries. ${ }^{21}$

- Chapter Four - Discuss how racial uplift and concepts of "blackness" have defined what Americans during White's time and now consider one's musical culture. Schenbeck's Racial Uplift will provide much needed insight to answer this question, in addition to White's position as an African American male playing an instrument and musical style associated with high art and the white elite. Was White considered to be less of an African American because he performed, taught and composed within a style created by white Europeans? How was the musical culture in the black community defined by white Americans? How was it defined by black Americans and how much was this definition influenced by mainstream culture? How could this have influenced black American classical violinists' reception and success not only in the mainstream but in their own communities? To help answer these questions, I will compare White to famed composer William Grant Still (1895-1978), whose early musical years in the late nineteenth and early twentieth centuries provide useful comparisons to White's upbringing. He was brought up on Western art music and hymns within the black church, yet was not exposed to the blues until later in life, a style synonymous with African American musical culture. ${ }^{22}$ I will draw attention to this similarity between their musical cultures in order to understand White's Western musical ethnocentrism.

${ }^{21}$ Ibid. Henry Roth, Violin Virtuosos: From Paganini to the $21^{\text {st }}$ Century [Los Angeles: California Classics Books, 1997].

${ }^{22}$ Willard B. Gatewood, "The Formative Years of William Grant Still: Little Rock, Arkansas, 18951911"in William Grant Still: A Study in Contradictions, ed. Catherine Parsons Smith [Berkeley: University of California Press 2000], 31, 35. 
- Conclusion - Through White's life and references to other black violinists, it is shown that, even within a period of history of racial divisions and racist policies there were many performers, teachers, and composers of Western art music that were not of white, European descent. I am not writing this thesis to create a hero or martyr out of Clarence Cameron White, his musical ancestors, or descendants. My aim is to acknowledge a portion of classical music history that needs more attention and more scholarly research. The books, articles and recordings that do exist on this topic are wonderful and without them I would not have such well-researched information and sources to draw upon. But the dispersion of this information needs to continue and more perspectives on this subject written. It is important to know that not all Western art music performers, teachers, conductors and composers have hailed from one continent or racial group. 


\section{Introduction: Exposure \& Limitations}

When Clarence Cameron White was six years old, he and his mother, Caroline White, saw a performance of Handel's The Messiah. After the performance, Mrs. White noticed her son "humming snatches" of the oratorio. ${ }^{23}$ This manifestation of her son's "good musical ear" prompted Mrs. White to ask his grandfather if Clarence could play his violin. His grandfather agreed, but with one condition: "if he ever plays at a dance I'll take it back." 24

Despite playing with a dance band to pay for his fourth year of study at Oberlin College ("to ease my conscience...I refused to play first violin.”), Clarence Cameron White studied violin throughout his collegiate studies and supported himself and his family as a performer, teacher, and composer. ${ }^{25}$ During his early performing years, he was regarded as the "best violinist of his race," "the Bronze Kubelik," (after celebrated soloist Jan Kubelik). He studied with some of the most celebrated black musicians of the late nineteenth and early twentieth centuries: Joseph Douglass, Will Marion Cook and Samuel Coleridge-Taylor. ${ }^{26}$ His career balanced performing, teaching, and composing. While giving recital tours in the continental United States, he was a collegiate professor, wrote articles and essays on violin technique and

${ }^{23}$ Vernon H. Edwards \& Michael L. Mark, "In Retrospect: Clarence Cameron White” in The Black Perspective of Music 9, no. 1 [Spring, 1981]: 53.

${ }^{24}$ Ibid.

${ }^{25}$ Edwards \& Mark, "In Retrospect”: 54.

${ }^{26}$ Southern, The Music of Black Americans, 277. Tim Brooks, Lost Sounds: Blacks and the Birth of the Recording Industry 1890-1919 [Urbana: University of Illinois Press, 2004], 493. 
music within the black community, and composed string quartets, a violin concerto, an opera, choral works and a variety of pieces for violin and piano. ${ }^{27}$

Outside of his compositional career, however, White's life is barely known or discussed within the narratives of Western art music history and black American musical history. He was not the only African American classical violinist who was active and successful in spite of living in segregated America. But his absence within the narratives of Western art music history and black American music history, respectively, suggests that no African Americans except Sanford Allen played the violin prior to $1960 .^{28}$ This assumption could not be further from the truth, but the Western art music narrative, which includes some black classical composers and performers such as William Grant Still, Harry T. Burleigh and R. Nathanial Dett, still has a far way to go in terms of providing a history that is reflective of the diversity that has existed within this style for over three hundred years. ${ }^{29}$ Discussing and analyzing White's career, his use of musical "uplift," and his place within American society will show that Western art music and classical violin study and performance has been a part of African American musical culture. I hope to add to the scholarship on White's performances and teaching to challenge the racial divisions that are tightly woven into musical styles and in turn the instruments associated with them.

${ }^{27}$ Victoria Von Arx, "Clarence Cameron White” in The International Dictionary of Black Composers, Vol. 2, Samuel A. Floyd, Jr., ed. [Chicago: Fitzroy Dearborn Publishers 1999], 1199-1206.

${ }^{28}$ Southern, The Music of Black Americans, 525.

${ }^{29}$ Dominique-René de Lerma, "The Chevalier de Saint-Georges” in The Black Perspective in Music 4, no. 1 [Spring 1976]: 3-21. Wyatt, "The Inclusion of Concert Music of African-American Composers in Music History Courses": 241. 
These racial divisions extend back to African musical practices, where the prevalence of percussion instruments in West African society became a cultural signifier in the accounts of Europeans and North Americans. ${ }^{30}$ Though drums were an important part of African musical cultures due to their social and religious significance, Western and Sub-Saharan African cultures also had stringed instruments. ${ }^{31}$ They were often "made of a narrow box, its open top covered with alligator or antelope skin, with a long stick used as a neck and a bridge to support the strings. ${ }^{, 32}$ Some were even made from gourds with “...three strings of horsehair, not in single hairs but a number for each string untwisted, the bow the same; the body of the violin was formed of half a long gourd; the bridge, two cross sticks; the top, the skin of a guana stretched tightly over the edges; the neck was about two feet long, ornamented with plates of brass, having a hollow brass knob at the end. ${ }^{, 33}$ These instruments were either bowed or plucked, depending on the traditions of the people. ${ }^{34}$

After the first African slaves arrived in the North American mainland in 1619, millions more were kidnapped and ripped from their homes to adjust immediately to a new society and life as slaves. ${ }^{35}$ This need to assimilate into colonial society, combined with the desire to

${ }^{30}$ Southern, The Music of Black Americans, 9-10.

${ }^{31}$ Southern, The Music of Black Americans, 12-13. Dave Dargie, "Umakhweyane": A Musical Bow and Its Contribution to Zulu Music" in African Music 8, no. 1 [2007]: 60-81.

${ }^{32}$ Southern, The Music of Black Americans, 12. Luvuyo Dontsa, "The Tonalities of the Isankuni" in The Galpin Society Journal 60 [April 2007]: 161-166.

${ }^{33}$ Ibid. John Brearley, "The Segankuru - A "Bush Fiddle" or a Bowed Bow?: Some of its Exponents and Their Songs" in Botswana Notes and Records 28 [1996]: 121-144.

${ }^{34}$ Ibid.

${ }^{35}$ Southern, The Music of Black Americans, 3. 
continue their music traditions and the cultural exchanges that happened amongst the variety of African tribes who now lived together on plantations, served as the catalysts for the development of African American music. Though Africans were discouraged from playing their traditional instruments, there were areas in the continental United States where African musical practice survived or were adapted and channeled through the use of traditional European instruments, such as the violin. ${ }^{36}$

The introduction of the violin to African Americans served two purposes: to provide musical entertainment for the masters and his guests and as a tool of assimilation into colonial society. Documentation from the late seventeenth century provides evidence of African American violin players, supplying a need that would not be met by professional musicians or gentleman: only servants or slaves provided music for dances and other social gatherings. ${ }^{37}$ The number of active black fiddlers in pre Civil War America presents a musical tradition much more active than the main narrative of American music history would suggest. Paul Well's "Fiddling as an Avenue of Black-White Musical Interchange" discusses this area of American music, revealing a musical practice that was active and allowed for white and black interaction that was not possible or allowed in many aspects of society. In addition to performing for all white or all black social gatherings, there were instances when fiddlers would play for mixed dances. Elizabeth W. Allston Pringle recounted a Christmas dance in the 1850s whose music contained elements of white and black American music making. The races of the performers are not mentioned, but the instrumentation, "a fiddle playing the gayest jigs," accompanied by

\footnotetext{
${ }^{36}$ Epstein, Sinful Tunes and Spirituals, 47.

${ }^{37}$ Epstein, Sinful Tunes and Spirituals, 112. Philip A. Jamison, "Square Dance Calling: The AfricanAmerican Connection" in Journal of Appalachian Studies 9, no. 2 [Fall 2003]: 388.
} 
"two heavy sticks knocking to mark the time" with "a triangle and bones" are examples of European and African musical traditions. ${ }^{38}$ "This was a great entertainment for all, white and black" and just one of many examples of whites and blacks interacting in casual settings. ${ }^{39}$

Where some colonial American communities encouraged slaves to play the violin and were recognized for their skill on the instrument, other communities saw the violin and dancing as degrading and sinful. ${ }^{40}$ One account links the sinfulness with violin playing and dancing in the profile of a female African American violinist, Clarinda, born in $1730 .{ }^{41}$ Her playing of the violin was proof, in the eyes of the author, of Clarinda growing up "in a state of ignorance unworthy of a Christian country."42 Her playing would "draw persons of both sexes together, who, not having the fear of God before their eyes, delighted like herself, in sinful and pernicious amusement." ${ }^{, 43}$ Clarinda would experience a spiritual epiphany in the midst of dancing, causing her to abandon her fiddling and dancing to become a preacher, living until the age of $102 .^{44}$

Documentation of black classical violinists extends as far back as the $18^{\text {th }}$ century. Le Chevalier de Saint-Georges was the son of an African slave and French plantation owner and a

${ }^{38}$ Paul Wells, "Fiddling As An Avenue of Black-White Musical Interchange" in Black Music Research Journal 23, no.1/2 [Spring-Autumn, 2003]: 139.

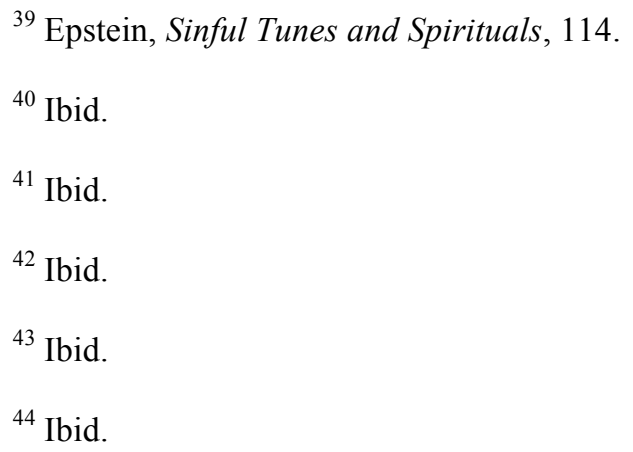


popular composer and violinist who spent the majority of his career in Paris. ${ }^{45}$ Edmond Dédé, a New Orleans native born in 1827, studied violin at the Paris Conservatory and settled in Bordeaux in $1868 .^{46} \mathrm{He}$ directed the L'Alcazar Theater orchestra before returning to New Orleans in 1893-1894 and giving several concerts (two decades later, Clarence Cameron White would provide a biographical sketch of Dédé in his "The Musical Genius of the American Negro" article, which will be discussed in a later chapter). ${ }^{47}$ Another successful classical violinist and composer of African descent was José (Joseph) White, born in Cuba in 1836, though earlier sources contain conflicting dates. ${ }^{48}$ White studied primarily in France and was considered "one of the most distinguished violinists of the French school," in addition to being "a composer of note." ${ }^{49}$ He would also be featured in Clarence Cameron White's article.

Clarence Cameron White came of age and studied violin in a very different social and cultural climate than the three men described above. He was born in 1880 in Clarksville

${ }^{45}$ Dominique-René de Lerma, "The Chevalier de Saint-Georges": 3-21. Gabriel Banat, "Le Chevalier de Saint-Georges, Man of Music and Gentleman-At-Arms: The Life and Times of An Eighteenth-Century Prodigy" in Black Music Research Journal 10, no. 2 (Autumn 1990): 177-212. Clague, "From Commodity to Creator."

${ }^{46}$ Southern, The Music of Black Americans, 252. Lester Sullivan, “Composers of Color of NineteenthCentury New Orleans: The History Behind the Music” in Black Music Research Journal 8, no. 1 [1988]: 54-58. Lucius Wyatt, "Six Composers of Nineteenth-Century New Orleans" in Black Music Research Journal 10, no.1 [Spring, 1990]: 127.

${ }^{47}$ Ibid.

${ }^{48}$ Vega, Aurelio de la, "White Lafitte, José” in Grove Music Online http://www.oxfordmusiconline.com.www.libproxy.wvu.edu/subscriber/article/grove/music/30221?q=José+White\&s earch=quick\&pos=1\&_start=1\#firsthit (accessed March 28, 2015). Josephine Wright, "Violinist José White in Paris, 1855-1875" in Black Music Research Journal 10, no. 2 [Autumn 1990]: 213-232.

${ }^{49}$ Southern, The Music of Black Americans, 253. 
Tennessee, fifteen years after the official end of the Civil War, shortly after the end of Reconstruction, and received the majority of his violin training in American institutions. ${ }^{50}$ During Reconstruction (1865-1878), southern African Americans saw short-lived advancements in educational and social opportunities: the passage of the Fourteenth amendment granted newly freed slaves American citizenship, the Fifteenth amendment ensured the voting rights of black men, and schools such as Howard University, Hampton and Tuskegee Institute were founded to provide education to the newly freed American populace. ${ }^{51}$ This new access to voting power and educational opportunities led to the election of African Americans to legislative bodies in the South, though this move towards equality would be short lived with the creation and passage of legislation to reinforce the social and racial structures that kept African Americans disenfranchised and impoverished. ${ }^{52}$ Even amidst this struggle for social power and influence, black Americans in the North and South were utilizing and creating opportunities for social and economic advancement. One method was to redefine and recreate what it meant to be "Negro.",53

${ }^{50}$ Edwards \& Mark, "In Retrospect”: 51; Brooks, 492.

${ }^{51}$ Garrett Epps, Democracy Reborn: The Fourteenth Amendment and the Fight for Equal Rights in PostCivil War America [New York: Henry Holt and Company, LLC 2006].

${ }^{52}$ Stanley J. Folmsbee, "The Origin of the First "Jim Crow" Law" in The Journal of Southern History 15, no. 2 [May 1949]: 235-236. Henry N. Drewry and Humphrey Doermann, Stand and Prosper: Private Black Colleges and Their Students [Princeton: Princeton University Press, 2012], 19.

${ }^{53}$ Paul Allen Anderson, Deep River: Music and Memory in Harlem Renaissance Thought [Durham: Duke University Press, 2001], 115. Floyd, ed. Black Music in the Harlem Renaissance: A Collection of Essays [Westport: Greenwood Press 1990], 4. 
Stereotypes that have and continue to plague African Americans are multifaceted, whether black men or women are the primary focus. Either "docile" and "noble" or "violent" and "savage," African, and in turn, African American culture had been understood and critiqued through the lens of the dominant culture. ${ }^{54}$ These views were also applied to musical traditions. Blackface entertainment had been present within American society prior to the American Revolution but it was not until the 1820s and 30s that it became a significant part of American theatre. ${ }^{55}$ In the early 1830s, Thomas Dartmouth Race's "Jim Crow" became "one of the best-known and most-loved theatrical" personalities of his time, creating the first major blackface minstrel caricature. ${ }^{56}$ Blackface performers used exaggerated imitations of black speech, mannerisms, and music that many white audiences interpreted as legitimate portrayals of black life. ${ }^{57}$ The popularity of minstrelsy created a public perspective that regarded white American's interpretations of black life more trustworthy than those who were actual participants in the culture. The legacy of black minstrel stereotypes remained into the twentieth century, continuing to perpetuate African Americans as shiftless, incoherent and prone to violence. $^{58}$

The lack of control over their own cultural representations led many African Americans to respond through emphasis on education, community support (particularly through the

${ }^{54}$ Katrina Dyonne Thompson, Ring Shout, Wheel About: The Racial Politics of Music and Dance In North American Slavery, [Urbana: University of Illinois Press, 2014], 8.

${ }^{55}$ Thompson, Ring Shout, Wheel About, 165-166.

${ }^{56}$ Thompson, Ring Shout, Wheel About, 168-169.

${ }^{57}$ Thompson, Ring Shout, Wheel About, 4.

${ }^{58}$ Bill Barlow, "Minstrelsy" in The New Encyclopedia of Southern Culture [Chapel Hill: University of North Carolina Press 2014], 89-90. 
church) and economic success. The ideological movement, known as "racial uplift" would become a significant part of black intellectual rhetoric in the late nineteenth century. ${ }^{59}$ Combined with the legalization of African Americans' rights as citizens and in spite of the deeply entrenched racism, the possibility of achieving equal status with whites was more real than it had ever been. The lifestyles, achievements, and education of middle and upper class African Americans served to not only show lower-class, poor blacks what could be accomplished through education, hard work, dedication and faith but also to illuminate to white Americans that blacks were capable of success. They could run their own businesses and schools, as well as create and critique their own artistic forms. ${ }^{60}$ Their successes and failures not only reflected on their self-worth and their family but on their entire race.

As a son of Oberlin College graduates and descended from free African Americans through his mother, it is likely that White was aware of the importance of education for a young African American boy in a segregated, racist society. ${ }^{61}$ Through his interviews and writings on classical violin and music in the black community, it is clear that he was cognizant of the racial problems of his native country and was taking steps to address and destroy those divisions.

\section{Methods of Discussion and Analysis}

Before we delve into White's early years of study, it is necessary to understand how the study, performance and composition of Western art music by African Americans was

${ }^{59}$ Gene Andrew Jarrett, Representing the Race: A New Political History of African American Literature

[New York: New York University Press 2011], 73-100.

${ }^{60}$ Anderson, Deep River, 114-115.

${ }^{61}$ Edwards \& Mark, "In Retrospect”: 51. 
emblematic of many social and cultural layers. Due to the vast number of layers, this thesis will only discuss two that are imperative to understanding White's place within the history of Western art music and African American music. The first layer will be his place within Western art music as an African American classical violinist. His education and early years of performance occurred in a unique era of violin history, where the performance aesthetic in violin playing shifted from austere and academic interpretations to a warm, sensuous tone and expressive musicality, aided by the increased use of vibrato. ${ }^{62}$ Only two recordings of White's playing exist, but they fail to give a complete understanding of his technical and expressive musical arsenal. ${ }^{63}$ Therefore, it is necessary to reframe his repertoire selections, recital reviews, and pedagogical writings to understand what technical abilities were important to him as an instructor and how they might have been manifested in his playing.

The second layer will be the racial, social and cultural implications of a black man playing classical violin, and how it might have been viewed (in his own time and our own) as "outside" of his cultures' musical experience. Due to the racial divisions enforced by de jure and de facto segregation and the inevitable racism used to support that system, White's place within this art form and within the history of this instrument may seem anomalous. But as we have seen, he was not the first African American to play the violin. As observers of historical events, it is easy to assume that due to the strict segregation in America there was little to no interaction or exchange between whites and blacks and thus no musical exchange, assimilation and integration. This assumption could not be further from the truth.

${ }^{62}$ Roth, Violin Virtuosos, 104. Robert Philip, Performing Music in the Age of Recording [New Haven: Yale University Press, 2004], 193.

${ }^{63}$ Brooks, Lost Sounds, 494-495. 
Due to the complexity of this topic, this discussion of White's career will use a combination of historical, racial, and cultural analysis. This will provide a historical narrative that shows the presence of African American within classical violin study and pedagogy while also addressing and exploring the cultural and racial significance of White's performances, writings and teaching. The works of Dena J. Epstein, Lawrence Schenbeck, and Eileen Southern utilized historical approaches that would best serve in placeing White's life within the history of violin study in African American communities. Epstein's Sinful Tunes and Spirituals focuses on the musical practices of African Americans in pre-Civil War America with the assimilation of European instruments to preservation and recreation of musical traditions from their respective cultures. Epstein draws from a variety of primary sources to better understand the various forms of black musical production that occurred in this time period. These accounts of musical events and individual performers, while not without the biased views of the observer, provide many examples of African Americans performing European folk tunes on the violin. ${ }^{64}$ The use of first hand accounts solidifies Epstein's retelling of this period of African American musical history and shows the importance of the use of primary sources in understanding White's pedagogical philosophy and audience reactions to his performances.

The Music of Black Americans by Eileen Southern presents a chronologically detailed history of black American music, beginning with the musical traditions in Western Africa. Southern also provides biographical information on Clarence Cameron White, Joseph Douglass, Sissieretta Jones and many other African American classical violinists, pianists, vocalists, composers and teachers active in the nineteenth and twentieth centuries. ${ }^{65}$ The inclusion of

${ }^{64}$ Epstein, Sinful Tunes and Spirituals, 112.

${ }^{65}$ Southern, The Music of Black Americans, 246, 277, 283. 
African American concert music culture and Southern's detailed listing of its participants and their careers provides a narrative that acknowledges the variety of musical expressions that have existed within African American communities.

Racial Uplift and American Music 1878-1943 by Lawrence Schenbeck adds to the literature on black classical music through a historiography of performers, patrons, composers and intellectuals. Schenbeck provides a variety of case studies from W.E.B.Du Bois' creation and staging of the historical/mythological pageant The Star of Ethiopia, R. Nathaniel Dett's use of black folk idioms in Western art music forms to White's application for funding for a Rosenwald Fellowship. Schenbeck's book is rooted in historical perspective and cultural critique with recognition of the need for further scholarship on black concert music "to remedy neglect caused by years of racial prejudice." ${ }^{66}$ While each case study is focused on a particular individual within the history of black American concert music, Schenbeck's overarching narrative provides a chronological look at its use as a tool for uplift.

The following materials of Houston Baker Jr., Samuel A. Floyd Jr., Ronald Radano, and Guthrie Ramsey Jr. addresses the use of race in scholarship either as a tool to understanding the intersections of race and musical expression or to showcase the ways African Americans have navigated the limiting social criteria placed on their creative potential, what Baker described as the "mastery of form." ${ }^{, 67}$ It is impossible and irresponsible to not consider the function of race within White's life and career. Through discussion of his pedagogical writings and essay on black American musical history and progress, it may be possible to understand how he viewed

\footnotetext{
${ }^{66}$ Schenbeck, Racial Uplift, 12.

${ }^{67}$ Houston Baker Jr., Modernism and the Harlem Renaissance [Chicago: The University of Chicago Press
} 1987], 22. 
himself as an African American classical violinist and the social function of Western art music study, composition and performance in black American communities.

Floyd's The Power of Black Music explored the "musical tendencies," "mythological beliefs and assumptions," and "interpretive strategies" within African music that were continued and nurtured during the creation of African American music, retaining what Floyd described as "African cultural memory."68 Floyd's intention was three-fold: (1) to show the ever present, African elements that supported the creation of a variety of black musical styles, (2) to provide a method of scholarly research for these styles, (3) and to break the barriers between "high" and "low" music. ${ }^{69}$ Through this approach, Floyd presented the complexity, structure and historic lineage of African American musical styles that had continuously been viewed as lacking form or historical context. Rather than present this music as free from race, Floyd set his narrative in the midst of it, showing the expressions of identity and history through musical soundings. His approach and material is significant in the chronicling of "African cultural memory" through his discussion of a variety of black musical styles including Western art music. Though the majority of the classical pieces featured are for voice and piano, Floyd presents a narrative that includes Western art music as part of the African American musical narrative, showing that many composers did not see it as "outside" of their experience. $^{70}$

The use of race in the study of black music is discussed in Guthrie Ramsey's “The Pot Liquor Principle: Developing a Black Music Criticism in American Music Studies.” Ramsey

\footnotetext{
${ }^{68}$ Floyd Jr., The Power of Black Music, 5.

${ }^{69}$ Ibid.

${ }^{70}$ Floyd, Jr. The Power of Black Music, 102-105, 226-266.
} 
addresses the need for a methodology in black music criticism and the importance of race in the analysis and understanding of African American musical scholarship. Despite the shift in musicology in the 1980s and 1990s that allowed for study and critique of repertoires considered "unworthy of serious study," Ramsey felt the advances in black musical scholarship had yet to address the layers of complexity that lay within its topics. ${ }^{71}$ Though he suspected that musicologists would begin to utilize methods of research and critique from other areas of black cultural study, he believed this approach would increase through a greater amount of participation by black scholars:

Why? Because I believe that the theorized social experiences of black critics (and audiences, too, for that matter) need to form an integral component of the emerging profile of black music criticism. ${ }^{72}$

The importance of black scholars critiquing and researching black musical history also ties into Ramsey's opinion that it is not always in the best interests of the author or his/her readers to separate the cultural and social experiences of their subject matter. Even the experiences of the author could be used to inform the racial, cultural and social analysis of black music, as Ramsey explains through his own negative experience with police. His car mistaken for a fleeing suspect's, Ramsey was nearly arrested until the police viewed his Penn I.D. ${ }^{73}$ Such an experience may seem to rest outside of the concern of black music scholarship, but when one considers the history of black Americans' relationship (or lack thereof) with the police, such anecdotes may only serve to understand the social context of the times:

\footnotetext{
${ }^{71}$ Guthrie Ramsey Jr., “The Pot Liquor Principle: Developing a Black Music Criticism in American Music
} Studies" in American Music 22, no. 2 [Summer, 2004]: 285.

\footnotetext{
${ }^{72}$ Ibid.

${ }^{73}$ Ramsey, “The Pot Liquor Principle”: 290.
} 
Such social matters are always mediating one's intellectual life, whether these connections are explicitly stated of not. It is my contention that the social experience of critics and audiences do matter and should be considered an important component of the profile of cultural analysis. ${ }^{74}$

Another important observation of Ramsey's is the use of elements of essentialism: the view that specific peoples and cultures have differences that are directly related to their natures and dispositions. Ramsey does not hesitate in acknowledging that essentialism has been used to promote racist ideologies but cautions against removing it completely from scholarly research: "Not all notions of essentialism need to be considered racist per se; some exist as powerful displays of human agency, intention, and culture building." ${ }^{.75}$ Ramsey's support of the use of race and elements of essentialism are not to encourage the crippling view that the "behaviors, worldviews, collective intellectual development" of a people provided complete understanding of their culture. ${ }^{76}$ Instead, Ramsey calls for acknowledgement that "all communities have wellformed ideas about who they are in the world and what behaviors, world views, and cultural practices define them best. ${ }^{, 77}$ Recognizing these communal differences is not equal to strengthening racial divisions. Rather, it encourages an understanding of difference and acknowledgement of racial and cultural variety without falling into the hole of looking at music through a lens of sameness, or as Ramsey describes it, "universalistic blindness." ${ }^{.78}$

While The Power of Black Music contains an essentialist approach and Ramsey calls for the use of race in the discussion of American and African American music studies to address the

\footnotetext{
${ }^{74}$ Ramsey, "The Pot Liquor Principle": 291.

${ }^{75}$ Ramsey, “The Pot Liquor Principle”: 287.

${ }^{76}$ Ibid.

${ }^{77}$ Ibid.

${ }^{78}$ Ibid.
} 
variety of complex musical, cultural and racial issues inherent in many American genres, literary critic Houston Baker Jr.'s landmark book Modernism and the Harlem Renaissance explores a more specific method of analyzing the African American literary and musical expressions that contributed to the formulation of a modern black cultural and artistic consciousness. ${ }^{79}$

Baker's intention was to reframe the modernist developments of the Harlem Renaissance as articulations of the black experience and crafting of a new understanding of black identity. Rather than comparing black modernism to the modernist movements of European cultures, Baker called for an understanding of this cultural movement within the framework of black American culture, showing that the Harlem Renaissance was not a failure but an expression of different priorities and perspectives. ${ }^{80}$ The concerns, fears, hopes and dreams of African American modernists were expressed through the adoption of Western literary forms ("the mastery of form") which were then deconstructed to communicate the soundings of black American cultural thought ("the deformation of mastery"). ${ }^{81}$ This method, learning the rules in order to break them, allowed African Americans to find their voices within a culture that consistently marginalized, belittled and subjugated them. To understand and appreciate this mastering and deconstruction of form, it is imperative to also alter one's academic approach if a complete understanding and analysis of the material is to be undertaken.

Understanding the various "soundings" present in black musical practice is the primary goal of Ronald Radano's Lying Up A Nation. However, he does not want to expound and encourage the various and persistent stereotypes that have plagued black music for over three

\footnotetext{
${ }^{79}$ Baker, Modernism and the Harlem Renaissance, 8.

${ }^{80}$ Baker, Modernism and the Harlem Renaissance, 8-9.

${ }^{81}$ Baker, Modernism and the Harlem Renaissance, 7-8, 15.
} 
hundred years. Rather, his "ultimate aim is...to provide a historical theory that defends the magical, miraculous quality of black performances" in the face of societal limitations. Radano argues that African American music "derives neither from a simple African origin nor from an inherently "spiritual nature” that seemingly “ "jes grew.' It emerges instead from the alchemy of modern racial logic and the ironic differences that logic produces." ${ }^{\prime 82}$ To understand American music is to understand the function and place of race in America, and Radano's intention is to recraft the narrative of black American music. Instead of its distinct characteristics naturally emerging from the ether of social struggle and growing cultural pride, black American musical styles, forms and aesthetics are varied and reflect "historical complexities of cultural production" in a people's journey and fight for artistic self-expression. ${ }^{83}$ As Ramsey wrote of the importance of race and social experience in the understanding of black music, Radano's analysis is grounded in this acknowledgement: the creation of a black music, "black sounds," would not have been possible without the existence of racial divisions and the resulting creation of "black" and "white" essences. $^{84}$

Race in American society is a powerful social tool that has created divisions based on differing physiology ${ }^{85}$ It is a segment of society that should not be impossible to ignore but is uncomfortably easy to. Even with the abolishment of racist policies, racist structures remain within American society and one of those remnants is the view of non-white cultures from the

\footnotetext{
${ }^{82}$ Radano, Lying Up A Nation, 13.

${ }^{83}$ Radano, Lying Up A Nation, xiii.

${ }^{84}$ Radano, Lying Up A Nation, 4.

${ }^{85}$ George M. Fredrickson, The Black Image in the White Mind: The Debate on Afro-American Character and Destiny, 1817-1914 [New York: Harper \& Row 1971], xi-xiii.
} 
perspective of white American cultural standards and norms ${ }^{86}$ Within our current musicological climate, it is not uncommon to find hundreds of books and articles on the history of jazz, blues, Duke Ellington and Louis Armstrong. ${ }^{87}$ African American musicians and black musical idioms continue to receive the scholarly treatment they have so long deserved. But African American concert music and classical violinists have yet to receive such ubiquitous treatment. Though articles and bibliographies on black classical string players and violinists have been assembled, they have yet to be fully integrated into the main narrative. ${ }^{88}$ With the focus and attention placed on jazz and the blues, the musical history of black America is distorted and leaves hundreds of people past and present outside of the narrative. While I do not wish to overshadow the details of White's study, performance and teaching of the violin with discussions and investigations of race in America society, it is imperative to understanding his life, not only because he lived during a time when racism and discrimination were legal and societally accepted but because that residue is insidiously present in our current society.

It should not be denied that the origins of any music style are rooted in the culture of its creator and contributors. What becomes problematic is the use of a musical style to serve as the

${ }^{86}$ Eduardo Bonilla-Silva, "The Invisible Weight of Whiteness: The Racial Grammar of Everyday Life in Contemporary America" in Ethnic \& Racial Studies 35, no. 2 [Feb 2012]: 173-194.

87 Robert Ford, ed. A Blues Bibliography: The International Literature of an Afro-American Music Genre, $2^{\text {nd }}$ Edition [New York: Routledge, 2007]. Janice Leslie Hochstat-Greenberg, ed. Jazz Books in the 1990s: An Annotated Bibliography [Lanham: Scarecrow Press, 2010].

${ }^{88}$ Suzanne Flandreau, "Black Music in the Academy: The Center for Black Music Research" in Notes 55, no. 1 [Sep 1998]: 26. Guthrie P. Ramsey, Jr., "Who Hears Here? Black Music, Critical Bias, and the Musicological Skin Trade" in The Musical Quarterly 85, no. 1 [Spring 2001]: 1-52. "The Black-White Divide in Cultural Pursuits" in The Journal of Blacks in Higher Education, 58 [Winter, 2007/2008]: 13-15. 
sole creative signifier of an entire culture. This in turn creates limitations for musicians, particularly those who perform music "outside" of their cultural heritage and are thus heard with skeptical ears. African American musicians and ensembles of Western art music were viewed as performing repertoire "unnatural" to their racial and cultural disposition one too many times. Two incidents featuring ensembles from Fisk University reflect those societal limitations, communicated directly or indirectly. Though African American Western art music performers did receive positive reception, it was often tapered by biased racial expectations and assumptions from their mainstream audience.

The Fisk Jubilee Singers are perhaps the most well known all-black vocal ensemble of the nineteenth century. The reactions of their audience affected the Singers' repertoire and stylistic decisions, the latter of which would aid in the transition of spirituals into the realm of Western art music. ${ }^{89}$ Initially, the members were against adding these pieces to their concerts. One member recalled:

The slave songs...were associated with slavery and the dark past, and represented things to be forgotten...they were sacred to our parents who used them in their religious worship...We did not dream of ever using them in public. Had Mr. White suggested such a thing, we certainly had [sic] rebelled... Occasionally two or three slaves songs were sung at the close of the concert. But the demand of the public changed this order. Soon the land rang with our slave songs. ${ }^{90}$

The success of the Fisk Jubilee Singers' tour allowed Fisk University to pay off their debts and resulted in the group touring Europe twice, the second tour lasting for three years. ${ }^{91}$

\footnotetext{
${ }^{89}$ Anderson, Deep River, 18.

90 James Haskins, Black Music in America: A History Through Its People [Thomas Y. Crowell Company,
} 1987], 28-29.

\footnotetext{
91 Haskins, Black Music in America, 29.
} 
While it is notable that an all-black, non-minstrel ensemble received artistic praise and success with white American and European audiences in post-Civil War America, it is imperative to realize that their stylistic choices, while aiding in "raising" the spirituals also placed them in a cultural quandary. Most European Americans' understanding of black vocal music was marred by minstrelsy, and hearing "white" performance styles emerge from black bodies was a contradiction in the opinions of various observers and critics. The early descriptions of the ensemble as "a band of negro minstrels" blatantly exposed the limits of many white Americans' understanding of black American music. ${ }^{92}$

This view was still present many decades later. New York Times music critic Olin Downes wrote a review of a Fisk University Choir performance in 1933. Their performance lacked "the wildness, the melancholy, the intense religious feeling communicated when Negroes sing in the sacred spirit and the uncorrupted manner of their race." ${ }^{93}$ Intellectual and activist W. E. B. Du Bois wrote a response, saying that Downes' review suggests that African Americans should cater to the expectations of their audiences rather than be acknowledged for their talents. "The Negro chorus has a right to sing music of any sort it likes and to be judged by its accomplishment rather than by what foolish critics think that it ought to be doing." 94

Downes' statements are problematic because they suggest that performance styles and aesthetics of black American music styles are inherently related to black musical performance and thus, black musicians. ${ }^{95}$ With these conflations of music, race and culture, these situations

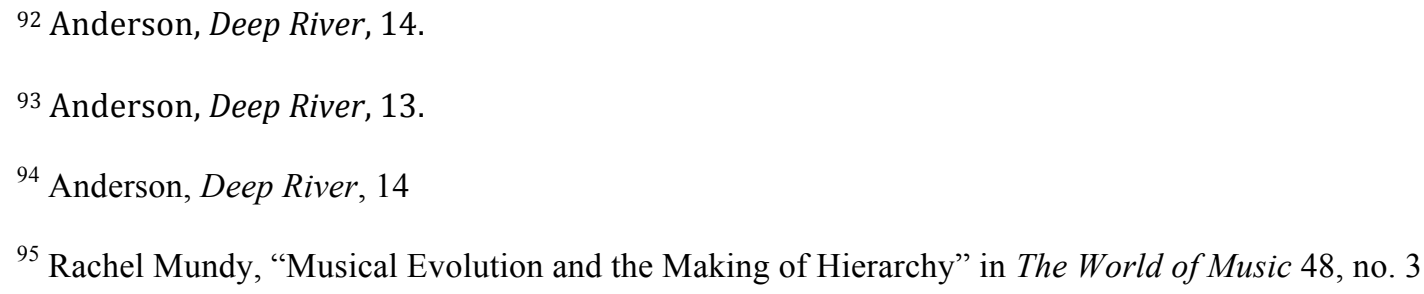


show how the expectations of the dominant society influenced and attempted to influence the musical and stylistic choices of African American musicians and composers. Though the success of the Fisk Jubilee Singers challenged white Americans stereotypes of the creative and artistic capabilities of African Americans, the belief that spirituals were authentically black and influenced the ensemble's repertoire selections and reveals that African American musicians could not simply be appreciated by their talents. ${ }^{96}$ They were still required to fill a certain role, to wear the "minstrel mask."97

But in spite of these limitations, many black classical musicians and performers studied, performed, composed, and taught Western art music. My goal with this thesis is add to the previous scholarship that shows their presence within this musical form and assist in the breakdown of racial limitations that have encased Western art music and African American music history. However, I want to ensure that my intention to inject White into both the Western art music does not present White's life as a story of "transcending” the limitations of his race. Reading on the era of his life brought forth some questions that are often thrown around with little to no awareness of their destructive capabilities: "Because White played classical music, was he ashamed of his blackness?" "Was he ashamed of black culture?" Such inappropriately simple questions must be asked and answered as they have been constantly flung at blacks whose artistic, literary or musical tastes do not conform to the dominant culture's definition of “blackness." Sometimes they do not conform to the black community's definition of "blackness."

But there are millions of black people in America. There are many black communities. And with these many communities come many individuals whose ideas of "blackness" align and

\footnotetext{
${ }^{96}$ Schenbeck, Racial Uplift, 37.

${ }^{97}$ Baker, Modernism and the Harlem Renaissance, 17.
} 
diverge. White's place within a musical style and cultural sphere rooted in the cultural standards of the dominant culture does raise some challenging, complex questions as to how he viewed black musical idioms. As we shall see, he was one of several that saw the societal ascent of African Americans as being synonymous with their adaptation and mastery of white cultural forms. To consider him "less black" because of this betrays a lack of understanding of the complex relationship between African Americans' cultural autonomy and the expectations of the majority. That simple, insulting quip, "Was he truly black?" denies the diversity within Western art music history and the variety of musical expression with the African American community. My hope is that this thesis will help to break down the stereotypes that still cling to American musical styles and show that there are a variety of expressions of "blackness," that being African American and playing classical violin are not, and never have been, mutually exclusive. ${ }^{98}$

The methodologies of these scholars have aided in my growth, questioning and understanding of the best ways to approach the areas of White's life. Because of these various layers: race, social structure, violin pedagogical history and the history of the study and performance of the violin in the black American community, this thesis will implement a weaving of all these scholarly approaches. First, we will take a look at the presence of the violin within African American classical music culture, not only as a tool of assimilation but as an example of the cultural exchange that occurred very frequently in pre-Civil War as the racial divisions in America became more defined. We will also discuss the popularity of spirituals in the nineteenth century and how their positive reception aided in songs and vocal works becoming

${ }^{98}$ Kyla Kupferstein, "Young Eight to Black Youth: There Are Classical Musicians Who Look Like You” in The New York Amsterdam News [June 16, 2005], 37. 
synonymous with African American music, overshadowing the instrumental study and performance within the black community. 


\section{Chapter One \\ "I Definitely Made Up My Mind To Be A Violinist": Education \& Connections}

Clarence Cameron White and his mother moved from Clarksville, Tennessee to Oberlin, Ohio after the death of his father in 1881 . Though he is quoted to have received his grandfather's violin at the age of six, another source says his music studies began at age eight. ${ }^{99}$ Both sources do agree that's White's first encounter with African American violinist Will Marion Cook was at the age of eleven. ${ }^{100}$ Upon his mother's remarriage, the family relocated to Washington D.C. in 1890, which had a healthy and supportive black music scene. ${ }^{101}$ White "came in contact with numerous boys and girls" who were also music students and attended "many concerts" were he "heard the celebrities of that day." 102 One such celebrity encounter was with Will Marion Cook, "an incident... which really started my musical career.",103

Cook was to perform during a recital of pianist-teacher Alice Strange Davis’ students. "As usual a program by pupils is rather a long-drawn-out affair," and White fell asleep and missed Cook's performance. ${ }^{104}$ When he awoke, he "burst out crying and made such a fuss that my mother had to hustle me out of the concert and I went home in disgrace." ${ }^{105}$ Cook asked about the upset young boy, located White and his family and offered to teacher him for the

\footnotetext{
${ }^{99}$ Brooks, Lost Sounds, 492.
}

${ }^{100}$ Edwards \& Mark, "In Retrospect”: 53. Brooks, Lost Sounds, 492.

${ }^{101}$ Doris Evans McGinty, "The Washington Conservatory of Music and School of Expression” in The Black Perspective in Music 7, no. 1 (Spring 1979): 61.

\footnotetext{
${ }^{102}$ Edwards \& Mark, "In Retrospect”: 53.

${ }^{103}$ Ibid.

${ }^{104}$ Ibid

${ }^{105}$ Ibid.
} 
summer: "Every lesson was one of pure joy, and it was during this period that I definitely made up my mind to be a violinist."106

White did not resume lessons until the age of fourteen, when he became a student of Joseph Douglass, another popular and successful black violinist (and abolitionist Frederick Douglass' grandson). ${ }^{107}$ After high school, White studied at Howard University from 1894-95 before transferring to Oberlin College in $1896 .{ }^{108}$ Several sources say White left Oberlin in 1901 to accept a teaching position, while another says he did complete his degree program. ${ }^{109}$ What is known for certain is that White studied with two black classical violinists who were very successful within their respective careers. Will Marion Cook, best remembered as a composer of musical theater and "his pioneering achievements in popular songwriting, black musical comedies and syncopated orchestral music." ${ }^{110}$ The son of a Howard University graduate, Cook studied violin at Oberlin College (1883-1887), the Hochschule für Musik in Berlin from 1887 to 1889 and composition with Antonin Dvoŕák at the National Conservatory in $1893 .{ }^{111}$ His studies at the latter institution were assisted through a fundraising recital organized by Frederick Douglass, who was contacted by Cook's mother. ${ }^{112}$ Joseph Douglass' music education is less

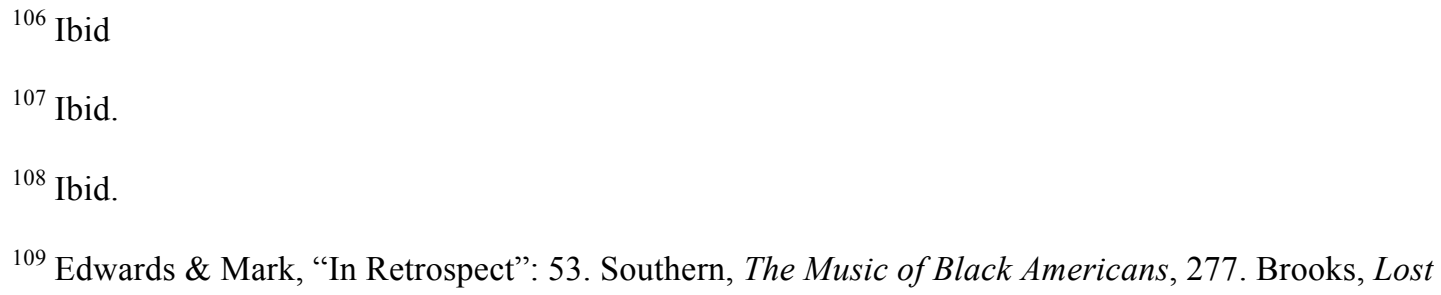

${ }^{110}$ Marva Carver, "Removing the 'Minstrel Mask' in the Musicals of Will Marion Cook" in The Musical Quarterly 84, no. 2 [Summer 2000]: 207.

${ }^{111}$ Carver, Swing Along, 12, 19, 28-31.

${ }^{112}$ Carver, Swing Along, 17. 
clear. His introduction into the narrative of American musical history begins in August 1893 on “Colored American Day" at the World's Exposition in Chicago, where he performed several classical violin pieces. ${ }^{113}$ Created through the joint efforts of Will Marion Cook and Paul Laurence Dunbar and with the assistance of Frederick Douglass, Cook was granted permission from President Harrison to sponsor concerts within the World's Exposition fairgrounds. ${ }^{114}$ Though some African Americans such as activist Ida B. Wells viewed a "Colored American Day" as a means of negative ammunition against black people, the event was nothing short of a success. ${ }^{115}$ Douglass was the first African American violinist to perform on transcontinental tours and a third generation violin player (his father and Frederick Douglass played the violin). ${ }^{116}$ He also served on the faculties of Howard University and the Music School Settlement for Colored in New York in addition to running his own music studio. ${ }^{117}$

The availability of higher education for African Americans was rare to non-existent in pre-Civil War America. The first African American to study at an American institution was John Chavis in the late eighteenth century and the first degrees earned by African Americans were awarded to Edward A. Jones and John Russworm in $1826 .{ }^{118}$ The most well known institution to admit students regardless of race is Oberlin College. Founded in 1833, they opened admission to blacks and women two years later (though this inclusion did not result in immediate racial

\footnotetext{
${ }^{113}$ Southern, The Music of Black Americans, 283. Carver, Swing Along, 24.

${ }^{114}$ Carver, Swing Along, 23

${ }^{115}$ Carver, Swing Along, 23-24.

${ }^{116}$ Ibid.

${ }^{117}$ Southern, The Music of Black Americans, 284.

${ }^{118}$ Drewry and Doermann, Stand and Prosper, 32.
} 
diversity; White was the only black student in the conservatory's orchestra in the late 1890s). ${ }^{119}$ Howard University, Fisk University, Tuskegee Institute and Hampton Institute were all founded with the intention of providing education to the newly freed black American populace. ${ }^{120}$ Howard University was founded in 1867 , two years after nearly four million people were declared free, and soon after, citizens of the United States of America. ${ }^{121}$ Established with financial help from the Freedman's Bureau, Howard provided instruction in theology, law and medicine. ${ }^{122}$ The educational foundations of the university were rooted in the pedagogical system of white Northern missionaries and the faculty and administrative members consisted of whites and blacks in its early history. In an article published in The Journal of Negro History in 1918, author Dwight O. W. Holmes wrote of the racial diversity of Howard's teachers, board of trustees and faculty members (though no African American had served as president for a full term; several other appointments had always been filled by white Americans at the time of the article's publication). ${ }^{123}$

Both White and Cook studied at the Oberlin Conservatory of Music, and though their years of study were a decade apart, both studied with violinist Frederick Doolittle. ${ }^{124}$ Parts, if not all, of Oberlin's musical curriculum was modeled after their European contemporaries, focusing

${ }^{119}$ Drewry and Doermann, Stand and Prosper, 33. Carver, Swing Along, 12. Edwards \& Mark, "In Retrospect": 54

${ }^{120}$ Schenbeck, Racial Uplift, 19.

${ }^{121}$ Carver, Swing Along, 5.

${ }^{122}$ Ibid.

${ }^{123}$ Holmes, "Fifty Years of Howard University: Part II" in The Journal of Negro History 3, no. 4 [Oct, 1918]: 379 .

${ }^{124}$ Edwards \& Mark, "In Retrospect”: 53-54. Carver, Swing Along, 13. 
on European classical music, harmony and musical aesthetics. Students' lessons consisted of one student being instructed while the other observed and took notes. ${ }^{125}$ Though White attended nearly a decade after Cook study there, it is likely he was taught in a similar format. Oberlin Conservatory's director and two members of the piano faculty were alumni of the Leipzig Conservatory and used the harmony text of a former Leipzig professor, Ernest Richter. ${ }^{126}$

White's education at Oberlin was peppered with outside jobs to support his education. ${ }^{127}$ A performance at the White House led to more performances that financed his third year of study:

Between my second and third semesters I returned home for a vacation. My parents had a friend, Arthur Wells, an employee at the White House. I don't known how he did it, but before I knew it I received an invitation to play for President McKinley and his guests. ${ }^{128}$

Oberlin's educational system used "the principle of compensatory education" which combined work with study to prepare them for the work force and make contacts within their respective fields. ${ }^{129}$ This is most likely why White was allowed to travel and give performances in the midst of his studies; rather than perceived as considering his future career as more important than his education, White's performances were putting what he had learned to a practical use, further preparing him for the life of a solo violinist (much more effective than waiting tables).

Whether White completed his degree or not, it is agreed that after his studies at Oberlin, he accepted a teaching position in Pittsburgh, Pennsylvania that did not last for longer than a

${ }^{125}$ Carver, Swing Along, 13.

${ }^{126}$ Carver, Swing Along, 12-13.

${ }^{127}$ Edwards \& Mark, “In Retrospect”: 54.

${ }^{128}$ Ibid.

${ }^{129}$ Edwards \& Mark, "In Retrospect”: 53. 
month. ${ }^{130}$ White returned home before leaving to continue his studies in Boston. ${ }^{131}$ He was waylaid in New Haven, where he applied and won a scholarship from the Hartford School of Music to study for one year with Franz Micki, head of the violin department. ${ }^{132}$ Between the failure of the Pittsburgh position, teaching at the Washington Conservatory of Music and writing for The Negro Music Journal, finding steady employment as a black classical violinist was far from easy, compounded by the fact that he wanted to play classical music: "This was a dark period...there seemed to be no opening unless I joined a dance orchestra and somehow that didn't appeal to me."133

His break came during a concert in New York City. Whether this occurred in 1901 or 1902 is unclear, but he was still residing in Connecticut at the time. Baritone Harry T. Burleigh, pianist R. Augustus Lawson and poet Paul Laurence Dunbar, along with White, took part in concert held at the Manhattan Casino, attended by nearly four thousand people. In White's mind, this was the start of his career as a soloist, and within the next decade he performed throughout most of the eastern and northern American cities. ${ }^{134}$

In the midst of his touring schedule, White took time to contribute articles to The Negro Music Journal, a periodical published from 1902-1903 that served as the organ of the Washington Conservatory of Music in $1903 .{ }^{135}$ The Washington Conservatory of Music was

${ }^{130}$ Edwards \& Mark, "In Retrospect”: 54.

${ }^{131}$ Ibid.

132 Ibid.

${ }^{133}$ Brooks, Lost Sounds, 493.

${ }^{134}$ Edwards \& Mark, "In Retrospect": 54. "Musical Notes” in The Negro Music Journal 1, no. 9 [May 1903].

135،Frontispiece" in The Negro Music Journal 2, no. 14 [Oct. 1903]. 
founded by pianist and teacher Harriet G. Marshall and provided its students with a musical education that combined instruction of Western art music with the cultural and musical history of African Americans. Students analyzed spirituals in harmony classes, took courses on black music history and attended guest recitals and lectures on these histories by black musicians. ${ }^{136}$ The conservatory was also significant as the first black-owned and operated institution of its kind in the United States. ${ }^{137}$ It not only provided a European-style musical education to black students but a sense of identity: an awareness and understanding of their musical history and how it "evolved" into the "high art" genres of the Western concert tradition. ${ }^{138}$ White would serve as head of the string department of the Conservatory from its inception until his resignation in $1907 .^{139}$

White's contribution to the December 1902 issue, "The American Negro in Music: Later Generation, Part I," features profiles of successful and talented black classical musicians. White intends to encourage the "ambitious students" to aim for a place at the "top" of the musical hierarchy in their studies and future music careers. ${ }^{140} \mathrm{He}$ discusses the careers and training of several classical singers to support his belief and show his readers that "there is room at the top..." for talented, dedicated African American musicians. ${ }^{141}$ Out of the all the four singers

${ }^{136}$ Sarah Schmalenberger, "Shaping Uplift Through Music" in Black Music Research Journal 28, no. 2, [Fall, 2008]: 75 .

${ }^{137}$ Schmalenberger, "Shaping Uplift Through Music": 58.

${ }^{138}$ Schmalenberger, "Shaping Uplift Through Music": 75.

${ }^{139}$ Edwards \& Mark, “In Retrospect”: 55.

${ }^{140}$ Clarence Cameron White, “The American Negro in Music: Later Generation, Part I" in The Negro Music Journal 1, no. 4 [Dec. 1902]: 59.

${ }^{141}$ Ibid. 
discussed, E. Azalia Hackley is probably the most familiar to music history scholars and students, primarily for her pedagogical legacy in vocal performance (White would receive a scholarship from her to study in London in 1908). ${ }^{142}$

"Part II," appeared in the January 1903 issue. White begins the article with profiles of classical singers, Harry T. Burleigh, "perhaps our most finished musician” appearing in this brief account of successful, talented black concert musicians. ${ }^{143}$ Violinists are featured next and White includes profiles on Will Marion Cook and Joseph Douglass. The violinist portion concludes with brief sketches of Chicago based J. Johnson, Felix Weir, a student of Johnson and Gertrude Palmer. ${ }^{144}$ White's listing continues and ends with an overview of African American pianists, including Harriet Gibbs Marshall. ${ }^{145}$ For readers of a black-owned and operated music magazine, it was important to know and celebrate the accomplishments of concert musicians within the race. These articles provided such knowledge, featuring many established performers and talented students who would serve as inspiration for the next generation.

The need and desire for examples of successful black classical musicians and composers was manifested in the immense popularity and respect Afro-British composer Samuel Coleridge-

${ }^{142}$ Edwards \& Mark, "In Retrospect”: 53. Juanita Karpf, "For Their Musical Uplift: Emma Azalia Hackley and Voice Culture in African American Communities" in International Journal of Community Music 4, no. 3

(2011): 237-256.

${ }^{143}$ White, "The American Negro in Music: Later Generation, Part II” in The Negro Music Journal 1, no. 5 [Jan. 1903]: 77.

\footnotetext{
${ }^{144}$ White, "The American Negro in Music: Later Generation, Part II": 78.

${ }^{145}$ White, “The American Negro in Music: Later Generation, Part II”: 79.
} 
Taylor had in American musical communities, white and black. ${ }^{146}$ White had corresponded with Coleridge-Taylor since his Oberlin years, and appeared on Coleridge-Taylor's programs during his American visit in 1904. ${ }^{147}$ In 1908, White, his wife, pianist Beatrice Louise Warrick, and their children moved to London for White to study composition under Samuel Coleridge-Taylor and violin under Mikhail Zacharewitsch. ${ }^{148}$

This opportunity for White to study overseas undoubtedly had a positive effect on his credentials as a violinist and composer. Not only had he studied with a talented and celebrated composer, he had studied violin and composition in Europe. Only a few decades earlier, many American students of Western art music would travel to Europe to continue and refine their education. The establishment of classical music societies in the early 1800 s reflected a desire to provide some of the most highly respected music ever created to the people of the United States. ${ }^{149}$ While no longer English and eager to craft a Western art music identity unique to their European ancestors, American concepts of what was cultured and refined music were rooted in European aesthetic and stylistic standards. ${ }^{150}$ By the late nineteenth century, Western art music musicians such as Antonin Dvorák had migrated to the United States and with the establishment

\footnotetext{
${ }^{146}$ Doris Evans McGinty, "That You Came So Far to See Us": Coleridge-Taylor in America," in Black
} Music Research Journal 21, no. 2 [Autumn, 2001]: 197, 199-200.

${ }^{147}$ Edwards \& Mark, “In Retrospect”: 55.

${ }^{148}$ Edwards \& Mark, “In Retrospect”: 55-56.

${ }^{149}$ Schenbeck, Racial Uplift, 42.

${ }^{150}$ Ibid. 
of American music conservatories and symphony orchestras, it was now possible to study art music within the continental United States. ${ }^{151}$

Yet the study of Western art music in Europe was still regarded as ideal and illustrious. It was Western art music's origin and home to Paris, Vienna, Berlin, major centers of art music performance and education. ${ }^{152}$ Though White went to college and began his career during a time when many respected European composers, pedagogues and performers were migrating to the United States, the seal of approval and respect that accompanied study in Europe was still a part of the Western art music community. Combined with the low expectations placed on African Americans by mainstream America, the need to succeed and possess the highest level of education from respected teachers in one's field was doubly important to middle and upper class African Americans. As mentioned before, with the development of uplift ideology and the importance in acquiring education, these achievements were believed to not only aid the individual but the entire race. White and other successful individuals would show white America that African Americans were competent, intelligent and worthy of equal treatment and respect in the large society.

The lives of White, Douglass and Cook overlapped in a variety of ways. Cook may not have studied in Berlin without the organizational assistance of Douglass' famous grandfather. White's lessons with Cook inspired him to become a violinist and a few years later, he studied

${ }^{151}$ Joseph Horowitz, "Dvoŕák and the New World: A Concentrated Moment” in Dvoŕák and His World, Michael Beckerman, ed. [Princeton: Princeton University Press, 1993], 92-93.

${ }^{152}$ Wright, "Violinist José White in Paris, 1855-1975": 214-215. Dawn Elizabeth Bennett, Understanding The Classical Music Profession: The Past, The Present and Strategies For The Future [Aldershot: Ashgate, 2008], 59. 
with Douglass. ${ }^{153}$ The close proximity of these three men may be a simple coincidence of being in the same place at the right time, but that explanation is too simple. White lived during a time when "separate but equal" was the law in several southern states, and the Western art music culture in the United States was in no rush to bring black concert musicians into the fold. This led to the creation of institutions such as the Washington Conservatory of Music and other institutions for black students of Western art music, the National Association of Negro Composers and black orchestras, choirs and small ensembles. ${ }^{154}$ While White did not seek out Cook or Douglass to study classical violin, it is clear, not only from his own words but in consideration of American society at that time, that his interactions with these two black classical violinists showed White that he could succeed in a field that was rarely if ever receptive to African Americans being included in their ranks.

And yet we have several examples of popular, successful and remembered African American concert musicians who were lauded in their time and are placed prominently within the history books. The Fisk Jubilee Singers, Harry T. Burleigh, and Roland Hayes, to name a few, were all were talented, successful vocalists and ensembles that are remembered for their performances of spirituals and/or their arrangement of spirituals within the art song form. ${ }^{155}$ With the spirituals' popularity amongst white audiences and their discussion in the writings of black intellectuals such as W. E. B. Du Bois and Alain Locke on their racial, cultural and social function, the performance of these songs by vocalists, choirs and instrumentalists would

153 Ibid.

${ }^{154}$ Southern, The Music of Black Americans, 287-296.

${ }^{155}$ Elizabeth Nash, Autobiographical Reminiscences of African-American Classical Singers 1853-Present: Introducing Their Spiritual Heritage Into the Concert Repertoire [Lewiston: Edwin Mellen Press, 2007]. 
contribute to the prominence of vocal music in the history of African American concert music and the voice as a symbol of black American musical expression. ${ }^{156}$

Before the Fisk Jubilee Singer's 1871 tour redefined the performance venue of spirituals, white Americans had been fascinated with the genre many decades earlier. Through the writings of Frederick Douglass and other slave narratives, the function of spirituals within black slave communities were shared through the eyes of those who witnessed and participated. Douglass' accounts on the spirituals addressed the misconception that the enthusiastic, passionate musical expressions was evidence of joy:

I have often been utterly astonished, since I came to the north, to find persons who could speak of the singing, among slaves as evidence of their contentment and happiness. It is impossible to conceive of a greater mistake. Slaves sing most when they are unhappy. The songs of the slave represent the sorrows of his heart; and he is relieved by them, only as an aching heart is relieved by its tears. ${ }^{157}$

The accounts of many white Americans tended to focus on the pathos and energy present during the performances of spirituals, especially in religious contexts. ${ }^{158}$ Though Douglass' writings would inspire and contribute to the spirituals use by white abolitionists to show the human suffering and pain inflicted on those enslaved, the unique quality of spirituals: aural aesthetics, performance style and group function compared to white American and European musical styles, dominated the writings of white Americans who witnessed this form of black music making. Of particular interest was witnesses feeling the spirit, as relayed by Frederick Law Olmsted in the

${ }^{156}$ W. E. B. Du Bois, The Souls of Black Folk [New York: Barnes and Noble Classics 1903, 2003], 177-

187. Alain Locke, ed. The New Negro: Voices of the Harlem Renaissance [New York: Touchstone 1925, 1997].

${ }^{157}$ Schenbeck, Racial Uplift, 27.

${ }^{158}$ Schenbeck, Racial Uplift, 29. 
1850s, who felt "my own muscles all stretched, as if ready for a struggle- my face glowing, and my feet stamping.,"159

The increase in white American's accessibility and exposure to spirituals led to the collection and publication of the songs in written form, such as Slave Songs of the United States, compiled by three abolitionists in the $1860 \mathrm{~s} .{ }^{160}$ While encouraging the recognition of a black musical idiom, white Americans' praise of spirituals was nonetheless peppered with stereotypes that limited and ignored the creative structures of African American music. The intro of Slave Songs perpetuates one of these musical stereotypes, the "barbaric character" only appearing "in short passages," of the spirituals, suggesting that anything outside of the barbarous character is somehow unnatural to African American music performance. ${ }^{161}$ Though the authors do acknowledge the cross-pollination of musical styles that led to the creation of the spirituals, the above stereotype of black music was accepted in nineteenth century ideas of Western ethnocentrism, understanding other cultures through the cultural standards of European and American society. ${ }^{162}$

This categorization of musical traditions as emblematic of race also contributed to comments such as those made by Olin Downes of black musicians lacking the "passion" and "wildness" that characterized accounts of black musical practices dating back to the fourteenth century. ${ }^{163}$ The Fisk Jubilee Singers' interpretation of the spirituals, performed and arranged in the tradition of Western art music, simultaneously made these songs suitable for recitals and

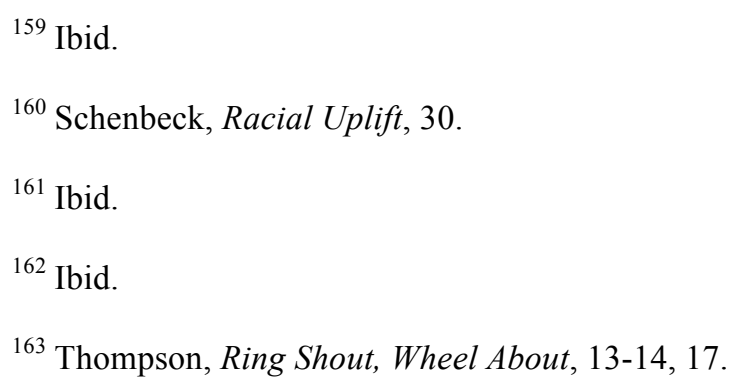


salon performances while also confusing some of their white audience members who saw their stylistic choices as foreign to their cultural heritage. But this confusion did not dissuade other black classical vocalists from studying classical voice, programing spirituals on their recitals and arranging them as art songs. Harry T. Burleigh, Roland Hayes, Margaret Bonds and Clarence Cameron White are just a few composers and performers who used spirituals and black music idioms as the creative basis for art songs, character pieces and choral works and included them in their performance repertoire. ${ }^{164}$ Through their inclusion of black vernacular music in a Western art music context, black classical musicians were able to master and deconstruct the forms within the musical hierarchy to gain attention and respect from whites while simultaneously ensuring their musical voices and ideas were heard and recognized. ${ }^{165}$

The symbolic and literal power of the human voice has also contributed to its focus within the context of black American history, musical and cultural. With the complete ownership of the black body in pre-Civil War America, ownership that manifested in ideological, insidious ways after 1865, one of the few things black Americans could control (to some degree) were their voices. Though most slaves were encouraged to sing ("A silent slave was not liked, either by masters or overseers.") to ensure the location of the slaves was known ("It was a means of telling the overseer, in the distance, where they were and what they were about."), the "signifying" within the lyrics of the spiritual and musical "cries" and "hollers" allowed enslaved

${ }^{164}$ Willis Patterson, "The African-American Art Song: A Musical Means for Special Teaching and Learning” in Black Music Research Journal 16, no. 2 [Autumn 1996]: 304. Ann Sears, “A Certain Strangeness": Harry T. Burleigh's Art Songs and Spiritual Arrangements” in Black Music Research Journal 24, no. 2 [Autumn 2004]: 227-249.

${ }^{165}$ Baker, Modernism and the Harlem Renaissance, 15. 
African Americans to express their experiences of their people and as individuals. ${ }^{166}$ With this tool African Americans slaves used to exert their personal autonomy, they would be recognized and lauded for their musical accomplishments and creations while simultaneously being denied basic human rights. Additionally, other forms of music making within the black community that did not conform to white America's understanding and opinions of black American music were humored if not ignored. One of these areas was classical violin performance. As will be shown in the following chapters, this exclusion, sometimes more intentional than accidental, did not stop White and other black classical instrumentalists from carving out a niche for themselves in the black community and receiving positive reactions from white communities in America and abroad.

${ }^{166}$ Schenbeck, Racial Uplift, 26. Tammy L. Kernodle, "Having Her Way: The Blues As The Black Woman's Lament” in Women's Voices Across Musical Worlds [Boston: Northeastern University, 2004 ], 215. Patterson, "The African-American Art Song": 305. 


\section{Chapter Two \\ White's Pedagogy in The Negro Music Journal}

The purpose of this chapter is to place White's teaching career within a historical and pedagogical context. The connections between American violin pedagogy of the early twentieth century and European violin pedagogy of the mid-late nineteenth century will be discussed from the perspective of White's pedagogical history and how they are present within his thoughts and opinions on violin teaching and important technical aspects. His writings and comments on the function of music in the black community as a cultural and social tool of uplift will also be discussed.

Clarence Cameron White wrote two books on violin technique and scale study. Copies of The Violinist's Daily Dozen, Twelve Special Studies for the Development of Correct Finger Action in Violin Playing (1924) and A System of One Octave Scale Studies For The Violin (1915) are housed in the Library of Congress. These books are, unfortunately, not available at this time, so our look into White's pedagogy will not be all encompassing until a later time. Therefore, his articles regarding violin technique within The Negro Music Journal will serve as the primary source of his ideas on violin pedagogy and their place within the history of American violin pedagogy.

White's private violin instruction lasted longer than most of his contemporaries. Private study often ended with the scheduling of concert engagements as the transition from student to concert violinist. White did not stop seeking instruction after his concert tours became solidified and plentiful. Announcements published by The Negro Music Journal speak of his many concert engagements throughout the United States. Despite many well-received performances dating back to his years of study at Oberlin (1896-1901), White continued to study privately with various instructors, ending his studies in London in 1911 with Russian violinist Mikhail 
Zacharewitsch. Upon his return to the US, he establishing a private studio in Boston and resumed his concert tours. $^{167}$

As noted before, White's collegiate education coincided with a variety of shifts in where people could access Western art music performances and educational institutions. The migration of European composers, teachers and performers to the United States and the establishment of symphony orchestras in major metropolitan centers in the mid-late nineteenth provided Americans with more direct access to "authentic" creators and performers of Western art music. ${ }^{168}$ The necessity for students of Western art music to travel overseas was slowly becoming less essential. However, the view that the best classical musicians, composers and educational centers were located in Europe was still present within classical music circles.

The inspiration and adaptation of European violin methods by violin instructors such as White provide a look into the continuation and deviation of pedagogical opinions and priorities of mid-late nineteenth century violin pedagogy. A variety of methods were in use at this time, so this will not be a thorough overview, but a look at the methods White's teachers learned and may have transmitted to him. This study will also examine the similarities and differences between his pedagogy and those of his teachers. "The Art of Violin Playing," his first article for The Negro Music Journal, was an overview of what White hoped to address in later articles, acknowledging that he had little room to provide comprehensive advice on every important aspect of artistic playing. ${ }^{169}$ His preface to the "violin department" outlines the importance of

${ }^{167}$ Edwards \& Mark, “In Retrospect”: 57.

${ }^{168}$ Ashley Cumming, "The Birth of the US Orchestral Audition” in Horn Call: Journal of the International Horn Society 45, no. 2 [Feb 2015]: 49.

${ }^{169}$ White, Clarence Cameron, "The Art of Violin Playing” in The Negro Music Journal 1, no. 1 [Sep 1902]: 2. 
bow and left hand technique and suggests technique books to use to improve each hand. Exercises by Henry Schradieck and Otakar Ševčik are referenced (spelled Shradieck and Serik in the printed article) in addition to scales and arpeggios to strengthen the left hand. White cites hearing a performance of violinist Jan Kubelik, one of his contemporaries and former student of Ševčik, as evidence of the exercises’ effectiveness. ${ }^{170}$ Ševčik was one of the most respected pedagogues of the late nineteenth and early twentieth century. ${ }^{171}$ Born in Bohemia (the current Czech Republic) in 1852, Ševčik studied at the Prague Conservatory, where he would return in 1892 to serve as a violin professor. ${ }^{172}$ His method books are still used by many modern violin teachers to develop and strengthen their students' technical abilities in the left and right hand. This focus on technical mastery and the praise of the technical ability of many of his pupils led to charges that his method placed technical gymnastics over tonal and musical nuance. ${ }^{173}$ As Amelia Christian observed in her dissertation “Ševčik’s Analytics of Works By Mendelssohn and Bazzini: A Pedagogical Analysis," the primacy of technical detail within the Ševčik method should not serve as evidence that Ševčik considered technical accuracy more important than musical expressivity. "No single avenue of study creates a complete artist. Neither technical exercises nor the written word can create a musical performance. Each component of a curriculum contributes to the final result..."174

${ }^{170}$ Ibid.

${ }^{171}$ Amelia Christian, “Ševčik’s Analytics of Works By Mendelssohn and Bazzini: A Pedagogical Analysis": 1.

${ }^{172}$ Martin Prchal, “The Man Behind the Exercises” in The Strad 109, no. 1301 [Sep 1998].

${ }^{173}$ Roth, Violin Virtuosos, 61.

${ }^{174}$ Christian, “Ševčik’s Analytics of Works By Mendelssohn and Bazzini”: 3. 
White did not study with Ševčik, though a brochure advertising his services and expertise as a teacher presents him as an instructor qualified to utilize the exercises and continue the method as crafted and taught by the highly esteemed pedagogue. ${ }^{175}$ White's advertising as a teacher of the Ševčik method most likely served to legitimize his own method. His articles in The Negro Music Journal were published prior to his studies in London and though they repeatedly mention Ševčik exercises, he did not promote them as the only means of improving one's technique. White's intention was to supply his readers with a variety of exercises that could help establish their technique and tone. Within his brochure, he presented his pedagogical philosophy and what he expects from his students:

He is a firm believer in the necessity of every violinist having absolute technic, and not alone in being able to do things so that they sound correct and pleasing, but in knowing how and why everything is done. It is probably because he has worked things out so thoroughly and logically for himself that he is able to make the process so clear to his pupils. ${ }^{176}$

His belief in focused, methodical practice to achieve "absolute technic" would remain one of the central tenants of his pedagogical method. White's writings suggest that he taught his students to understand "why" something was not working and "how" to fix the problem.

The introduction to the violin department in the February 1903 issue contains anecdotes about the "master of the violin" Niccolo Paganini, an overview of the basics of the violin and a listing of recommended methods books. He emphasizes the importance of a short talk about the violin between teacher and student "no matter what method one adopts," to ensure the teacher

${ }^{175}$ White, "Teaching Brochure” Clarence Cameron White Collection, Moorland-Spingarn Manuscript Division, Box 14.

176 Ibid. 
passes on "a great deal of his own knowledge of the violin...during the lesson." ${ }^{177}$ White's intention was to keep students and teachers current with the additions and advancements within violin pedagogy and performance. His sketch of Paganini's life was one of many he planned to write to inspire students reading the magazine. This short biography introduced a celebrated and talented violinist to White's readers and served as an example of the talent and ability that may be acquired through "thought and hard work" for all violin students. ${ }^{178}$ White used Paganini's life as a historical and pedagogical tool, providing students with an example of a man's technical and musical achievements that were cultivated and strengthened through hard work and dedication. He was clear to specify that "I do not mean to say that thought and hard work every student may become a Paganini, but I do mean that with talent and thought and hard work, we may produce what men sometimes call "genius."179

The importance of the bow within violin playing is the focus of issues from March until June of 1903. The March 1903 issue featured "Practical Hints on Violin Study," which contained specific instructions on how to hold the bow, its placement on the string, the angle of the arm and bad habits that may be acquired. White's intended audience appeared to be the student. Though he provided teachers with current info within the violin world, White's main goal with his articles was "to assist...the pupil who is ambitious and the pupil who will profit by advice."180 This shows in the detailed explanation of the bow hold. "The fingers of the bow should be held firmly but never rigidly..." and "All the fingers must be properly curved and near together, but never crowded." White describes the placement and function of each of the fingers: the first

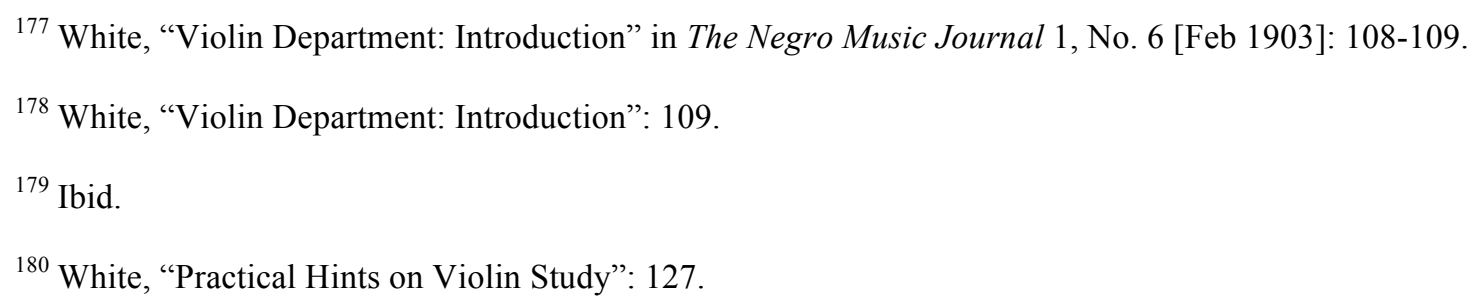


finger "is used to govern the tone-power on the up stroke," the little finger to "govern the tonepower on the up stroke, "...third finger helps to steady the general hold and balance of the bow," while second finger and thumb help hold the bow. ${ }^{181}$

The next paragraphs detail the physical reaction of the hand and arm when the bow is moved across the strings ("up" and "down"):

in the middle of the bow, the wrist will be about level with the forearm and hand from elbow to knuckle joint. When bowing at the nut, there may be a slight arching upward of the wrist besides its necessary bend in to the left. When bowing at the point of the bow, the wrist may be allowed to curve downward somewhat. ${ }^{182}$

These directions are still applicable to how many contemporary classical violinists are instructed in holding and moving the bow. The similarities diverge as White explains where the core movement for bowing should be made (the wrist) and to play on the side of the bow hair, though he clarifies that it is not necessary to play with flat hair all the time: "After touching the hair first on the outer edge, then press down with the fore finger to bring the whole width of the hair upon the strings, though in certain kinds of bowing the whole width may not be needed."

White's belief that the bow is the most integral aspect of violin playing is shown in this detailed guide to holding the bow and moving the bow arm. He had yet to write an article on how to hold the instrument itself. The bow was "the breath" of the violin, and White urged his readers to listen to singers to understand phrasing and musicality. White concludes with repertoire suggestions for beginning violinists, the importance of patience on the part of the teacher, and ensemble playing (i.e. group lessons) for more advanced students. ${ }^{184}$

\footnotetext{
${ }^{181}$ White, "Practical Hints on Violin Study": 128.

182 Ibid.

183 Ibid.

184 Ibid.
} 
The following article, appearing in the April 1903 issue, concerns bowing, holding the violin and the placement of the left hand fingers. Again, we see the prominence of the bow within White's pedagogy: “All the shading and phrasing in violin playing is done with the bow." ${ }^{185}$ He suggests practicing long tones with full bows on the open strings in front of a mirror, and "if the student is (as he should be) his own most severe critic," they will achieve a smooth, focused bow stroke. ${ }^{186}$ The necessity of a flexible wrist is also addressed, as some readers had written in requesting his opinion on the topic. White wrote of the connection between a flexible wrist and smooth transitions between changes of the bow "if the wrist is stiff the tones will have what my teacher use to call a 'kick.' The tones with a stiff wrist cannot blend.” He suggests practicing short bows at the "point" and the "nut" if the student has a stiff wrist.

"Holding the Violin" is concerned with leaving space between the thumb and first finger to allow smooth shifting rather than allowing the neck of the violin to rest on that part of the hand. He then moves to how the fingers of the left hand should be set on the string: "like little hammers...the elbow of the left arm is to be held far enough under the violin to allow the fourth or "little finger" to fall curved like the rest of the fingers." ${ }^{187}$ He suggests finger strengthening exercises such as Schradieck's “Finger Technique and Singers' Daily Studies” or scales by Schradieck or David. White directs the student to practice those scales two hours each day "with single strokes of the bow and slurred bowing....It will perhaps be dry work at first, but it will pay in the end." ${ }^{\prime 188} \mathrm{He}$ ends this article encouraging his readers to study and read about violin playing, violinmakers and violinists. He advises them to "study the lives of...Paganini, Ernst, Joachim,

185 White, "Bowing" in The Negro Music Journal 1, no. 8 [April 1903]: 153.

${ }^{186}$ Ibid.

${ }^{187}$ White, "Bowing": 154.

${ }^{188}$ Ibid. 
Ole Bull, Wilhelm, Vieuxtemps, Wieniawski, Joseph White, Remenyi, Sarasati and even the great genius Ysaye."

The May 1903 issue contains the "Styles of Bowing" article, though it is really a combination of right hand and left hand issues. White addresses bow distribution and to not sacrifice good tone when practicing this technique. He reinforces the importance of practicing short strokes near the frog, perhaps to ensure his readers to not forget the connection between soft wrist and smooth bowings. He mentions spiccato and staccato but does not delve into them as he will address these styles of bowing in a later article.

The remainder of the article focuses on left hand exercises and posture. White suggests Schradieck, Singer, and Ševčik, the latter being "the teacher of those two technical wonders Kubelic and Kocian. His book will work wonders towards strengthening the fingers." ${ }^{190}$ White emphasizes the importance of standing tall and not allowing the violin to slip down. "Hold your violin up!... Nothing looks so bad as that and yet it is a common fault of violinists." ${ }^{191}$ His final words are a sentiment that so many teachers have shared with students and constantly must remind them: "Practice all exercises SLOWLY: that is one great secret of success. Do not forget to drop us a line asking about anything you do not understand, and we will do our best to let you know anything that we can." 192

The tone of these articles shows that White was very serious about educating his readers and addressing any questions or concerns they had within their personal study and practice. Encouraging students to read about famous violinists and teachers to require their students to be

\footnotetext{
${ }^{189}$ White, "Bowing": 155.

${ }^{190}$ White, "Styles of Bowing" in The Negro Music Journal 1, no. 9 [May 1903]: 178.

${ }^{191}$ Ibid.

${ }^{192}$ Ibid.
} 
well read and knowledgeable about the history of the music and instrument they play is not too unfamiliar to many current students and teachers of the violin. White's list of important violinists includes Afro-Cuban violinist and composer Joseph (José) White, a contemporary of Wieniawski and Ernst. ${ }^{193}$ Without prior knowledge of his life, he would be perceived as another white European violinist. White makes no mention of his race, possibly due to this knowledge already existing within the black American community. In a time when the races of non-white peoples were often mentioned, even in black magazines and newspapers, it is intriguing that Joseph/José White's race is not mentioned or touted as an example of the "Negro race" excelling in an area known for its artistic and intellectual maturity. However, this would not be the first time White would write on José White, and his second writing, focusing on the musical achievements of African Americans, would place this violinist within a context where race was an important component of his essay.

"Styles of Bowing" continues in the June issue, where White explains how to practice spiccato and staccato. He discusses staccato first, and the intention behind the organization of his writings becomes apparent. The execution of slurred staccato would be difficult if not impossible without the use of a relaxed wrist: "begin at the point of the bow, and after starting the upward stroke with a firm pressure of the bow on the string, then relax the wrist muscles, and repeat the same thing all during the up stroke." ${ }^{194}$ He again suggests practicing in front of a mirror. Slow practice is also reiterated and that staccato would develop over many days of practicing. "When we begin to study this we must realize that we will not acquire a good stacatto bowing in a day nor a month either, - but it will require years of practice - slow practice - to obtain really good

${ }^{193}$ Clague, "From Commodity to Creator."

${ }^{194}$ White, "Styles of Bowing" in The Negro Music Journal 1, no. 10 [June 1903]: 205. 
results. ${ }^{195}$ He also suggests practicing on open strings and increasing the number of notes played within the full bow until the student can play a one-octave scale in one bow. Again, exercises are suggested, these written by Keyser, to be practiced for an hour daily.

White describes spiccato as "short, separate stroke(s) with springing bow." 196 The student is again instructed to practice the motions slowly and to be patient with their progress.

Begin very slowly to make a succession of short strokes in the middle of the bow and at the same time let the wrist be so loose that the bow will have a natural spring, at first, and gradually faster and faster until the stroke is even and clear...Both of the bowings require a great deal of patience as well as a great deal of practice. Do not become discouraged, even if you do not get these bowings a year or perhaps two years. ${ }^{197}$

The last few articles published that year addressed the left hand and third position. The July issues' "Left Hand" article reviews what White had covered in previously: keep a space between the neck and the hand, set the fingers on the strings with purpose to find the correct pitch and even tremolo (vibrato). White also writes on the importance of focused, consistent practice to improve and strengthen one's technique.

Always practice most the things that are hardest for you to do. Remember, a week or a month is not long to practice on something that is going to be "safe" for the rest of your career as a violinist. If you only "fiddle" on exercises, you will be bothered for the rest of your career with those things. Always be sure of a technical study before you go to the next. Always remember to review! It is not always the exercise you learn, but you are doing your fingers good. The fingers will be spoken of at length in our next writing. All questions relative to the subject will be gladly received."

In 1932, White succeeded R. Nathaniel Dett as Hampton Institute's director of music and conductor of the Hampton Singers. ${ }^{198}$ His essay "The Musical Genius of the American Negro"

\footnotetext{
${ }^{195}$ Ibid.

${ }^{196}$ White, "Styles of Bowing": 206.

${ }^{197}$ Ibid.

${ }^{198}$ Edwards \& Mark, "In Retrospect”: 61.
} 
was published a year later in Vol. 62 of The Southern Workman, a Hampton periodical. ${ }^{199}$ Another essay with the same name appears to have been published in The Etude in 1924, but is shorter than the article published within The Southern Workman. ${ }^{200}$ While his first articles for The Negro Music Journal profiled successful, contemporary African American musicians, this essay expanded his focus to the achievements of classical musicians of African descent and contributions of enslaved African Americans to the musical fabric of America.

The careers of Chevalier de St. George, José White, George Bridgetower and Samuel Coleridge-Taylor, to name a few, are given brief sketches. All except singer Ira Aldridge were violinists. As White moves from the historical to the more recent, this prevalence shifts noticeably from classical violinists to vocalists. White comments on this several times within the piece, revealing that most of the contemporary professional black classical musicians and rising stars of the time were singers or pianists. The brief portion of the essay that focuses on African American instrumentalists provides an enlightening perspective on a possible reason behind the lack of African American violinists within classical music ensembles:

There is today living in New York a Negro violinist who won the diamond medal upon graduation from a well-known Western conservatory, who was later a pupil of Becker at the Leipzig Conservatory, and who is now a member of a "jazz" band in New York. Another, a cellist of really great ability, a pupil for many years of both Schroeder and Schultz, is also a member of the same band. Several other Negro violinists are qualified and would rather fill a more dignified place in some body of symphony players. These cases are cited, not to show that Negros should be given places in Symphony orchestra simply because they are Negroes, but that they might be accepted in spite of that fact

${ }^{199}$ Clarence Cameron White, “The Musical Genius of the American Negro” in The Southern Workman 62, no. 3 [March 1933]: 108-118.

${ }^{200}$ Von Arx, "Clarence Cameron White" in The International Dictionary of Black Composers, Vol. $2,1203$. White, "The Musical Genius of the American Negro" in Jazz in Print: An Anthology of Selected Early Readings in Jazz History [Hillsdale: Pendragon Press 2002], 309-313. 
when they are qualified. ${ }^{201}$

During this time, orchestral auditions were not blind, allowing racist and sexist opinions and assumptions to cloud the objective judgment that is (theoretically) the primary purpose of the audition itself. White mentions two players who were members of highly respected symphony orchestras, but due to likely discrimination (or to increase their chances of being hired in the first place) described themselves as "Spanish" in public. ${ }^{202}$ Despite the positive attention many African American artists, musicians and thinkers received during the Harlem Renaissance, America's systemic racism would not be so easily removed. The cultural hierarchy that slowly developed to explain difference and excuse slavery in the late eighteenth century still kept black cultural signifiers and "blackness" at the bottom in the early twentieth century. Middle and upper class blacks were often very critical and kept vernacular black culture and its musical traditions at a distance, primarily due to its close associations with minstrelsy. ${ }^{203}$ To lead the race to social, cultural and economic stability required assimilation, conformity and mastery of white European and American cultural and artistic forms. ${ }^{204}$ White's classification of a symphony orchestra as "a more dignified place" for the two instrumentalists within that paragraph are just one example of his apparent low opinion of jazz. These articles and essay provide a glimpse into White's opinions regarding concert music and styles such as jazz that, while closely tied to African American culture and the black experience, he considered on the lower end of the musical hierarchy. The implications of this mindset will be explored in the final chapter, as it deals with

\footnotetext{
${ }^{201}$ White, "The Musical Genius of the American Negro": 114.

${ }^{202}$ Ibid.

${ }^{203}$ Schenbeck, Racial Uplift, 131.

${ }^{204}$ Schenbeck, Racial Uplift, 109.
} 
issues of race, culture, and musical styles and the ways that all three of these elements have become so intertwined that they are often seen as natural to the other.

The Negro Musical Journal articles show that White's pedagogy was rooted in the Western art music tradition. This is not so strange considering his entire education was within the tradition of classical violin playing. What makes this unique is that he does not specify that type of music that is the subject of his writings. Only through his references to people within European classical violin performance and pedagogy are we able to contextualize his focus and priorities. The importance of mental involvement and control not only pertained to bow control and left hand dexterity but to the study of a style that was cerebral and intellectual.

Within "The Musical Genius of the American Negro," though White aims to present the spirituals as an example of creativity and passion in the midst of inhuman situations, his description of this musical style perpetuates the stereotype of African Americans' "natural gift of song." 205 White's musical definitions of what was "refined" or "coarse" were undoubtedly influenced by his experience as a student and performing of Western art music, the symbol of refined human creativity. To achieve refinement and thus theoretically societal respect, one needed to play, teach and compose within this style. "Music" was Bach, Beethoven, Paganini, Mozart, and Haydn. "Music" aspired for something beyond earthly pleasure and enjoyment. This music would be a means to inspire and thus fix the social problems so many African Americans were facing. In addition to the establishment of conservatories for African American students, the creation of community orchestras within the black community were musical tools for uplift. The Boston Chronicle reported:

Community Service made a happy discovery of a practical way of social uplift by establishing an orchestra to give concerts in the South End. This project has from the

\footnotetext{
${ }^{205}$ White, "The Musical Genius of the American Negro": 109.
} 
first met with the hearty response of our people... Of all the different American groups there is none who loves music more than ours. To guide this love in wise channels, is the crux of our social problem... We believe that the salvation of the black man is just as possible with an orchestra as it is with a plough. ${ }^{206}$

White's opinions about racial uplift may not have changed between the years 1902 and 1933. The articles within The Negro Music Journal were primarily pedagogical and shared printing space with many other instructional writings and reports. However, it cannot be denied that, by the time White became involved with the Hampton Institute he was articulating methods to achieve racial uplift, writing on musicians not only to show African Americans that people like them were capable of mastering these forms, but to lead them to a place of cultural enlightenment and social equality. The study, performance and composition of Western art music forms for African Americans took on a duel function: it was another creative outlet for African Americans in addition to being a means to show white Americans that they were capable of deep, intellectual thought, critique and understanding.

I do not mean to insinuate that the only reason White studied the violin was to achieve a better standing in life. As he himself stated, he wanted to become a concert violinist because he wanted to become a concert violinist. His motivations were very simple, but their place within the larger, complicated context of American history places him amongst many other African Americans who performed in a style and in White's case, on instruments that were considered not of their culture. It was not uncommon for there to be more potential orchestral players than soloists; even in contemporary society, with all the concert violinists that are touring and performing with orchestras, there are hundreds of violinists who are and always will be orchestral players. The dearth of African American violinists playing in the major American

\footnotetext{
${ }^{206}$ White, “The Musical Genius of the American Negro": 115.
} 
orchestras and leading successful solo careers within White's time was not due to lack of ability as much as systemic racism.

White's pedagogy is indicative of a variety of methods and information from the various violin schools that existed in his early years of education. From his praise of Jan Kubelik's technical execution, it was not surprising that he would include certain methods and exercises from the violinist's celebrated teacher, Ševčik. His studies with Will Marion Cook, Joseph Douglass, Frederick Doolittle (who also taught Cook at Oberlin), Franz Micki, and Mikhail Zacharewitsch provided him with many different perspectives that were combined into his own unique method. From Cook, he was most likely exposed to aspects of the German violin school due to Cook's study at the Hochschule für Musik in Berlin. ${ }^{207}$ The dry and austere interpretations of Kubelik and other late nineteenth century violinists were falling away in the early twentieth century in favor of the tonally nuanced and expressive sound that came to define classical violin tone and interpretation, championed through the interpretive choices of Eugene Ysaÿe, Fritz Kreisler and Jacques Thibaud. ${ }^{208}$ The importance of the bow and the left hand "tremolo" within White's pedagogy place him within the emerging violin aesthetic: tonally rich and musical expressiveness through the use of the bow and knowledgeable application of vibrato.

Another important aspect of violin playing White address is mentally focused practice.

Within the March 1903 issue White, cites his own instructional history to support his position:

When a pupil begins the study of the violin, the all important thing for him to do is to learn how to play with the mind as well as the fingers and bow. I remember a book on bow technique I studied once,- at the very beginning of the first lesson, the words, "Think, think, think," were written across the page. Perhaps one "think" might have been sufficiently impressive; yet one needs to think more than once about anything connected

\footnotetext{
${ }^{207}$ Carver, Swing Along, 16.

${ }^{208}$ Roth, Violin Virtuosos, 20, 82, 104.
} 
with the study of music. ${ }^{209}$

This acknowledgment of the importance of mental awareness does not receive as thorough a breakdown in White's essays as the right and left hand techniques do, but it does show that White was aware of the required focus of the mind in order to play this instrument. Leopold Auer, one of the most well-known violin pedagogues of the early twentieth century (in no small part due to the famous violinists who passed through his studio, such as Jascha Heifetz), also wrote of the importance of mental focus and control in his introduction to Violin Playing As I Teach It:

By no means enough stress has ever been laid on the importance of mental work, on the activity of the brain which must control that of the fingers. And yet, unless one is capable of hard mental labour and prolonged concentration, it is a waste of time to undertake the complicated task of mastering an instrument as difficult as the violin. ${ }^{210}$

Auer's intro contains a list of the necessary abilities a potential student of the violin should posses: good sense of hearing and "adequate physical equipment." 211 Auer may be unique in this regard, as other methods books do not contain such criteria. ${ }^{212}$ This may seem irrelevant to point out except for the racial component within White's world and in the world of his readers. The Negro Music Journal articles never mention the necessity of aural or physical disposition to play the violin. The application of his instructions, use of suggested texts and dedicated practice would lead to positive results and advancement. Students could be viewed as having "inadequate

\footnotetext{
${ }^{209}$ White, "Practical Hints on Violin Study": 127.

${ }^{210}$ Auer, Violin Playing As I Teach It, ix.

${ }^{211}$ Auer, Violin Playing as I Teach It, $\mathrm{x}$.

${ }^{212}$ Karl Courvoisier, The Technique of Violin Playing: The Joachim Method [Mineola: Dover Publications,
} 2006]. Stefan Knapik, "Vitalistic Discourses of Violin Pedagogy in the Early Twentieth Century" in $19^{\text {th }}$ Century Music 38, no. 2 [Fall 2014]: 169-190. 
physical equipment" due to the size of their fingers (problems staying in tune when placing them on the fingerboard), or their skin color (this is not your "true" music!). There are many examples throughout American history of African American children being told that rather than studying to be a surgeon or an astronaut, a lawyer or a self-made businesswoman, they were better suited as a dentist, a farmer or a secretary. White's readers were most likely members of the black community and despite his writings serving to assist his student readers in their studies of the violin, it was also serving a duel purpose, whether that was White's intention or not. A student of the violin could succeed regardless of color: you could succeed with practice, focus and knowledge. Even White's writing in The Southern Workman was one of many responses to the racial limitations placed on African Americans. Through the use of writing and education through example and historical context, White was showing the presence of African Americans within Western art music history and classical violin in to show mainstream America and members of the black community that they could contribute great things to this musical style through study, passion and dedication. 


\section{Chapter Three \\ "One of the greatest players we have heard": Reviews and Repertoire}

This chapter will focus on some of Clarence Cameron White's performances from 1902 to 1949. Most of his recitals featured pieces that are rarely, if ever, performed in recitals or recorded in modern times. Looking at White's repertoire selections will provide some understanding of his technique and musical tastes by considering what technical issues and lyrical elements were present within the repertoire he programed. Recital reviews and press releases will also be discussed to see how his performances were received.

As has been noted, White was actively touring in the early 1900s. The "Musical Notes" section of The Negro Music Journal contains minor details of his continental tours, primarily the cities visited. During this time he performed primarily in northern cities: Chicago, New York, Boston, Cleveland and Buffalo. ${ }^{213}$ Within the May 1903 issue, White had returned to D.C. for a few days before leaving for a tour "of the Eastern and Western sections of the country. This enthusiastic young artist is fast gaining a national reputation as a violinist." 214

By the 1920s, White's performing locations had expanded to including southern cities. In

1924, The Oberlin Review wrote of White's tour and planned schedule after his rest in Oberlin:

After an extended concert through the south Clarence Cameron White, violinist-composer has returned home here. Mr. White was a student in the Conservatory from 1896 to 1901. He filled thirty engagements... His itinerary included Washington, Atlanta, Charleston, New Orleans, and other large southern cities, also Philadelphia and Cleveland. ${ }^{215}$

\footnotetext{
213 "Musical Notes" in The Negro Music Journal 1 no. 11 [July 1903].

214 "Musical Notes" in The Negro Music Journal 1 No. 9 [May 1903].

215 "Prominent Musician Makes Extended Tour" in The Oberlin Review 51, no. 38, Oberlin College
} Archives http://dcollections.oberlin.edu/cdm/ref/collection/p15963coll9/id/174347. (accessed March 24, 2015) 
While resting in Oberlin, White was preparing for another tour that would take him to "St. Paul, Denver, Seattle, Oakland, Los Angeles and other large cities of the west."216 This tour was given during the same year White became a violin instructor at the West Virginia State Institute and was president of the National Association of Negro Musicians. ${ }^{217}$ His performances in southern cities initially surprised me, yet Atlanta and New Orleans had significant black populations with healthy business and music communities. ${ }^{218}$ It is likely that White performed for all black audiences in those southern cities, as there were multiple venues that would not allow blacks to perform. Though it is unclear if black classical musicians had their version of the "chitlin' circuit," since there were many times black classical musicians performed for white audiences during this period, the majority of the venues they performed in were owned and run by African Americans. $^{219}$

However, it seems that White performed for whites and blacks, though not necessarily integrated audiences. Looking into press comments from his recitals dating from 1944-1949, it is interesting to note the differences in how his playing was described in white newspapers and black newspapers. Though positive reviews are listed from both sources, the reviews from black newspapers such as the Chicago Bee, Chicago Defender and Pittsburgh Courier of recitals given

\footnotetext{
${ }^{216}$ Ibid.

${ }^{217}$ Von Arx, "Clarence Cameron White", 1203. McGinty, A Documentary History of the National Association of Negro Musicians, 328.

${ }^{218}$ Alexa Benson Henderson, "Heman E. Perry and Black Enterprise in Atlanta, 1908-1925” in The Business History Review 61, no. 2 [Summer, 1987]: 216.

${ }^{219}$ Edwards \& Mark, “In Retrospect”: 54. Robert H. Cataliotti, “African American Music in Chicago During the Chicago Renaissance" in Writers of the Black Chicago Renaissance, ed. Steven C. Tracy [Urbana: University of Illinoi Press, 2011], 425.
} 
in the 1940s are often filled with descriptive, praising adjectives of his playing and worth as a person. A reporter from the Chicago Defender wrote: "It is unfortunate that two such brilliant concert artists as Marian Anderson and Clarence Cameron White should have been presented on the same day and at the same time. It places the music lover and concert-goer in a difficult predicament." ${ }^{220}$ This juxtaposition of White and Anderson, at least in the mind of the contemporary reader, places White on equal footing with a well-known figure within American musical history. It is interesting that one of these names has continued to be part of that history while the other is lesser known.

The following reviews do not contain specific dates could have occurred within the several of the later decades of White's performing career. The Defender recalled an afternoon recital given by White at a Kimball Hall: "Mr. White was at his best and played a program of exceptional merit, which gave ample opportunity to appreciate his gifts and artistry, due to study and mastery of the best in violin music." ${ }^{221}$ Covering a recital at Tuskegee, the reporter describes White's impression on the audience rather than his technical ability:

Aside from his art, Mr. White has a most engaging personality, and in playing there is a blending of his art and personality that has an appeal that is almost irresistible. There is that about it which makes you feel, not that he is performing for the display of his gifts, but rather that he is playing because he likes it, and more than that, because you like to hear it. It is this personal appeal that constitutes the charm of his recitals. ${ }^{22}$

This review is very interesting as it presents White as a gifted person not only due to his talent as a violinist, but through his performances within the community. White was respected not only

220 “Some Press Comments, November 1944” in Clarence Cameron White Collection, Howard University Moorland-Spingarn Research Center Manuscripts Division Col. 209 Box 14.

221 “Some Press Comments" in Clarence Cameron White Collection Box 14.

222 Ibid. 
because of his talent but because his passion for his field, his joy in sharing it with others, i.e., selflessness translated into community outreach. He was not just playing to show how talented and educated he was, he was doing so it give back to his community, one of the important aspects of racial uplift.

Whether these writers exaggerated White's abilities is a possibility that will always be a small voice at the back of my mind. However, the following reviews, much less glowing and praiseworthy than those above, do suggest that White was a talented and dedicated violinist (if the lengthy number of White's performance throughout his adult life was not enough of an indicator). His performance of Lalo's Symphonie Espagnole (referred to as "Spanish Symphony" in the review) "was played with depth of emotion and was much applauded." White had “excellent technical equipment, a good tone" and played "with rich expressiveness.,"223 "His tone is even more beautiful than last year - warm, velvety, joyous," wrote Musical America and Samuel Lacair of the Philadelphia Public Ledger wrote: "Clarence Cameron White, violinist, played Vitali's Chaconne with a fluent technique and fine tonal quality." 224 Two reviews from Paris and London, respectfully, were much less descriptive in their praise and judgment. Fanny Edgar Thomas on White: "You played superbly. You had a fine program. You are indeed to be congratulated," while the West London Observer simply characterized White as "a clever American violinist." 225 Thomas's review, while less descriptive than the American newspapers, still presents us with a reaction to White's playing and technique. From these reviews we may gather that he had a beautiful tone and was an emotive player. A review from a recital given in

$$
\begin{aligned}
& { }^{223} \text { Ibid. } \\
& { }^{224} \text { Ibid. } \\
& { }^{225} \text { Ibid. }
\end{aligned}
$$


Port-Au-Prince, Haiti (which, though lacking a date, was most likely during his trip in the 1920s for research for his opera Ouanga!), is perhaps the most glowing and praiseworthy of all the reviews listed on this program: "The violin recital offered by the American violinist, C. C. White, was a priceless treat, for he is a master in the full meaning of the term, one of the greatest players we have heard."226

The review from Haiti is undoubtedly the most glowing and praiseworthy. The praise he received was emblematic of his ability and the importance of sharing his performance to other blacks. With the rise of Pan-Africanism in the 1920s, White's trip would not only serve as a cultural study for his opera but as cultural exchange between African Americans and Haitians. ${ }^{227}$ The rest of the reviews appear to be from white newspapers but most were positive descriptions of technique and interpretation. White's trip but not all the reviews from white newspapers were lukewarm or dismissive. The reporter from Musical America had heard White more than once, commenting on his "warm, velvety, gorgeous" tone being "even more beautiful than last year."

These reviews also provide a look into what White performed and how he was received. Lalo's Symphonie Espagnole and Vitali's Chaconne are still staples of standard violin repertoire in contemporary times. However, as mentioned before, the majority of his recitals contain pieces that are not (or no longer) standard repertoire. White's programing was very different from other violinists, such as Ysaÿe or Kreisler. ${ }^{228}$ His normally contained no concertos but a mix of sonatas (sometimes one movement from a sonata) with salon pieces or slow movements from

\footnotetext{
${ }^{226}$ Ibid.

${ }^{227}$ Karen M. Bryan. "Clarence Cameron White's Ouanga! In the World of the Harlem Renaissance" in Blackness in Opera, ed. Naomi André, Karen M. Bryan, and Eric Saylor [Urbana: University of Illinois Press, 2012), 116-121.

${ }^{228}$ Roth, Violin Virtuosos, 30, 44.
} 
major concerti. The apparent uniqueness of White's programming may be rooted more in current standards of repertoire performed in violin recitals than in relation to his contemporaries. Though Kreisler and Ysaÿe programed Bach's unaccompanied sonatas and partitas and violin concertos that are now considered part of the standard repertoire, it is misleading to portray White's selections as anomalous. Rather, they appear to be examples of the variety of selections nineteenth and early twentieth century concert violinists chose from, some of which included music composed by the performer. ${ }^{229}$

One of the earliest examples of his recital programing appear in the "Musical Notes" section of the September 1903 issue of The Negro Music Journal. Held in Boston in July 1903, White's selections are largely non-standard violin pieces. If the De Beriot violin concerto performed during this recital was his Violin concerto op. 104 No. 9, the first movement of this piece is still studied and performed in modern times, though often by violin students. ${ }^{230}$ Unfortunately, it is not clear which violin concerto by De Beriot White performed that day. White also performed Perpetual Motion by Franz Ries, Gavotte by Carl Bohm, Caritina by Raff and Gypsy Song by Samuel Coleridge-Taylor. ${ }^{231}$ It seems that Caritina should actually be Cavatina: the latter was composed in 1859 as the third movement of Joachim Raff's 6 Morceaux, Op. 85 and later recorded by Itzhak Perlman, leading me to believe its title was misspelled in the

${ }^{229}$ John H. Baron, "Vieuxtemps (and Ole Bull) in New Orleans" in American Music 8, no. 2 [Summer 1990]: 212-213.

230 "Musical Notes" in The Negro Music Journal 2 no. 13 [Sep 1903]. Barbara Barber, Solos for Young Violinists, Vol. 4 [Miami: Summy-Birchard Music 1997], 22-24.

231 "Musical Notes" in The Negro Music Journal 2 no. 13 [Sep 1903]. 
periodical. ${ }^{232}$ Listening to Perlman's recording, Cavatina does not contain the technical gymnastics that has become an integral part of violin performance. It is a slow and lyrical composition that requires nuanced bow control and tonal depth. No reviews appeared in the publications I surveyed, so it is difficult to say how White would have interpreted this piece. However, there are recordings of White's playing, dating from 1919. Recording two movements from his Bandana Sketches, "Cradle Song" and "Lament," the latter selection allows us to glean how White's tone probably sounded in real life. ${ }^{233}$ "Lament" is slow and introspective and the importance White places on formulation of bow technique is evident in his thick, focused and round tone.

White programed one of his selections, Romance by Wieniawski, on a 1944 recital at the Wendell Phillip High School in Chicago and in 1947 at the Detroit Institute of Arts. ${ }^{234}$ The lack of specificity on the program presents a problem in identifying which of Wieniawski's romances White played. It could have been the second movement from the second violin concerto, op. 22, or the Romance sans paroles, op. 9. Both pieces are very lyrical, showcasing the violin's singing

\footnotetext{
${ }^{232}$ Joachim Raff, “6 Morceaux, Op. 85,” IMSLP, http://imslp.org/wiki/6 Morceaux,Op.85 (Raff, Joachim) [accessed April 22, 2015]. Raff, Encores, Itzhak Perlman \& Samuel Sanders, EMI 2003.

${ }^{233}$ Brooks, Lost Sounds: Blacks and the Birth of the Recording Industry 1891-1922 Archeophone Records
} B000BPDF4C, 2005.

${ }^{234}$ Clarence Cameron White and George W. Sherard, "Clarence Cameron White, School of Music \& Allied Arts Presents: Dr. Clarence Cameron White \& George W. Sherard, November $19^{\text {th }}, 1944^{\text {” }}$ in Clarence Cameron White Collection, Box 14. Clarence Cameron White and Henry Smith, "R. Dett Music and A. A. M. School Presents: 2nd Annual May Night Featuring: Clarence Cameron White in Violin Recital, May 27, 1947” in Clarence Cameron White Collection, Box 14. 
quality, though op. 9's variations contain moments of technical variety including spiccato, glissandi, double stops and harmonics as the piece progresses. The Romance sans paroles is not often performed within modern times in comparison to his op. 22 and other violin pieces. Scherzo Tarantella, a fiendishly difficult and flashy piece, Polonaise brilliante and Légende are more often performed and studied, most likely because each piece, though idiomatic to the instrument, are technically demanding and challenging. Whichever Romance he performed, White would have needed to utilize a full, controlled tone, directional phrasing and playing in the high register of the instrument. Performing only the second movement of Wieniawski's Concerto no. 2 in D minor should not be seen as an example of his lack of ability to play the first and third movements, but as a reflection of what White's technique he wanted to showcase. Many of his selections are slow, lyrical or both, and reflect the importance of tonal production and bow control that he advocated in his writings for The Negro Music Journal. If he had performed the "Romance" from Concerto No. 2 in D minor, op. 22 on these two recitals, it would have showcased his tone and lyrical phrasing and provided room to program a variety of works by different composers (sometimes White's own compositions). Concerto in A Minor by Antonio Vivaldi was also programed, but in comparison with the length of Romantic era concerti, this would not take up as much time as the entire Wieniawski op. $22{ }^{235}$

Another piece that appeared quite often was Norwegian composer Niels Gade's Sonata No. 2 in D minor (several times mistakenly labeled "in D major"). ${ }^{236}$ In a 1944 review published

\footnotetext{
${ }^{235}$ White and Sherard, "Dr. Clarence Cameron White and George Sherard, November 19 ${ }^{\text {th }}, 1944 . "$

${ }^{236}$ Bo Marschner and Finn Egeland Hansen, "Niels Gade" in Grove Music Online
} http://www.oxfordmusiconline.com.www.libproxy.wvu.edu/subscriber/article/grove/music/10464?q=Niels+Gade\&s earch=quick\&pos=1\& start=1\#firsthit. (accessed March 28, 2015). 
in the Pittsburgh Courier (though it is unclear if it is in reference to that particular recital at the Wendell Phillip High School), the reviewer provides some details of White's performance:

With George W. Sherard at the piano, Gade's "Sonata in D major" for violin and piano received intelligent artistic treatment with an alert allegro, sprightly, yet smooth larghetto and spirited allegro vivace. After each movement the musically intelligent audience gave thunderous approval of the work of both artists. ${ }^{237}$

While this reviewer comments more on the characters White conveyed rather than the technical aspects of his playing, this sonata would also showcase the lyrical ranges of White's playing in addition to his technical ability depending on how quickly he performed each movement.

The 1947 recital featured soprano Hazel Rice and the Nightingale Singers. White's repertoire selections are not as numerous but contains two interesting choices: a standard violin piece, Beethoven's Violin Sonata No. 2 Op. 30: Allegro con brio, and a composition of White's: Violin Concerto in G minor: Allegro E Maestoso. ${ }^{238 ~ "(F i r s t ~ T i m e) " ~ s i t s ~ u n d e r n e a t h ~ t h e ~}$ concerto's entry and was not the last time White would program this piece on his recitals. The remainder of his selections were his compositions: "Lament," "Valse Coquette," "On the Bayou" and Negro Dance."239

For his October 1949 recital at the Metropolitan A.M.E. Church in Washington D.C., White programed a different sonata and his violin concerto. ${ }^{240}$ The "Sonate Op. 13 by Rubinstein" was most likely the Violin Sonata in G Major, Op.13, composed by the nineteenth century

\footnotetext{
237، Some Press Comments, November 1944.”

${ }^{238}$ White and Smith, "Clarence Cameron White in Violin Recital, May 27, 1947."

${ }^{239}$ Ibid.

${ }^{240}$ White and Smith, “Clarence Cameron White, violinist, Metropolitan A.M.E. Church, October 14, 1949.”
} 
pianist Anton Rubenstein. ${ }^{241}$ Unlike the Gade, this sonata contains four movements and provides much more activity for the violin through character changes and forward motion, with portions in the high positions of the violin, spiccato, and swift changes from arco to pizzicato.

White's programing of his own material might seem self-serving and it likely was. Through these performances he was able to spread these violin selections to a wider audience and it was not an uncommon tradition for violinist-composers to perform their compositions. Fritz Kreisler famously programed "recently discovered" compositions from Baroque composers that were later discovered to be his own. ${ }^{242}$ White's violin concerto was recorded on violin and piano, but the piece itself remains unpublished. ${ }^{243}$

White also programed works by Samuel Coleridge-Taylor, such as his Ballade in C Minor op. 73, published in 1909 and dedicated to Mikhail Zacharewitsch. ${ }^{244}$ His inclusion of repertoire by a fellow composer of African descent helped disseminate these pieces and give them a wider audience. Yet his programing was not the first time violin works by black composers were featured on violin recitals. Kreisler recorded "Nobody Knows De Trouble I See"

${ }^{241}$ Edward Garden, “Anton Rubinstein” in Grove Music Online http://www.oxfordmusiconline.com.www.libproxy.wvu.edu/subscriber/article/grove/music/24053?q=Anton + Rubinst ein\&search=quick\&pos=1\&_start=1\#firsthit. $($ accessed March 28, 2015)

${ }^{242}$ Roth, Violin Virtuosos, 45-46.

${ }^{243}$ Robert Zimmer and Carl Atkinson, "Violin Concerto” Stark Recording Studios, Clarence Cameron White Collection Box 1. Von Arx, "Clarence Cameron White" in The International Dictionary of Black Composers, Vol. 2, 1199.

${ }^{244}$ Coleridge-Taylor, "Ballade in C Minor, Op. 73” Sibley Music Library, Eastman School of Music https://urresearch.rochester.edu/institutionalPublicationPublicView.action?institutionalItemId=16330. (accessed February 7, 2015) 
from White's Bandana Sketches. ${ }^{245}$ Jascha Heifetz, one of the most respected and technically proficient violinists of the twentieth century, programed Levee Dance and recorded it. ${ }^{246} \mathrm{~A}$ program from a Heifetz recital White attended in 1938 contains a short message and signature for the composer: "To Clarence Cameron White - With my compliments and all good words.."247

The programing of these compositions by two of the most popular classical violinists of the twentieth century was undoubtedly a proud moment for White, though this did little to bring attention to him as a composer. Despite such comments from Heifetz below, the violin works by African American composers would still review little to no attention from the Western art music community. Though Heifetz does not mentioned White specifically, it is clear he is aware of the stigma placed on American composers of art music:

I just feel that music by American composers ought to get a little better break... understand, I'm not playing these pieces simply because they are by Americans, but because I think they are good music. America is my adopted country, and as an American, I think I ought to have an opportunity to hear, whatever really good music is being created by our countrymen. ${ }^{248}$

The pieces to be performed are listed, but nothing of substance said about the composers of the “American set.” This erasure (intentional or not) of American composers' contributions to violin repertoire at this point in history reflected the ever-lingering belief that the works of native European composers were of larger substance than their immature American cousins. ${ }^{249}$ Despite the immigration of teachers, composers and performers in the late nineteenth and early twentieth

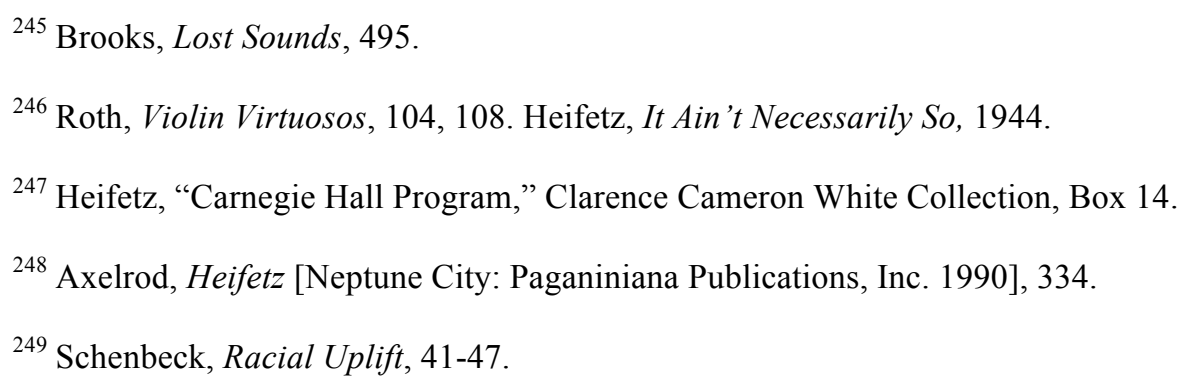


century from Europe to America, this viewpoint was hard to erase in a decade alone. ${ }^{250}$ The musical hierarchy of composition naturally extended to the performance world. Though American violinists such as Maud Powell, Albert Spalding and Louis Kaufman maintained successful performance careers in the first half of the twentieth century, within historical memory their careers and lives have not become integral parts of violin history such as Jascha Heifetz, Fritz Kreisler, and David Oistrakh.

The inclusion of race within this hierarchy only placed many black American classical instrumentalists at the bottom of the pyramid. The performance of White's pieces by Heifetz and Kreisler was a double-edged sword: though his works were performed, they did not contribute to success within mainstream classical music culture. ${ }^{251}$ While it was surprising and exciting to see that Heifetz, one of the most respected violinists in the instrument's history, had recorded a piece by an African American man in a time when "separate but equal" was the law of the land in the South and an unspoken law in the North, it did not erase the fact that White's works did not receive larger popularity or more extended dissemination. While Kroll's Banjo and Fiddle has become a fun, light-hearted piece that is often assigned to intermediate to advanced level players, Clarence Cameron White's Levee Dance, which contains rhythms that require good counting and subdivision skills, syncopations, phrasing indicators that are rarely seen in violin works and ability to change character immediately between phrases, is rarely, if ever played. ${ }^{252}$ William Grant Still's Suite for Violin and Piano, more specifically the second movement, "Mother and Child," has received more attention and performances thanks in no small part to its inclusion as

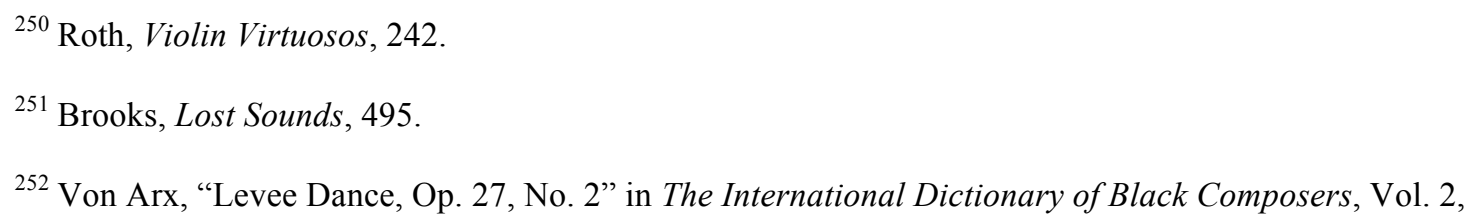


required repertory in the Sphinx Competition in past years. ${ }^{253}$ These pieces were not excluded because they were bad or technically impossible. They were not acknowledged within the wider violinist world because of racism. Not every participant of Western art music was consciously ensuring that this musical style would remain racial homogenous, but the lack of awareness and acceptance of a community active in the creation and performance of classical music reflects a much more disconcerting reality.

Post-Reconstruction America saw the passage of Jim Crow laws in the South to enforce an already stratified social structure that kept whites and minority groups in separate spheres of influence and maintained "white supremacy" within the political arena. ${ }^{254}$ There were financially successful African Americans during the late nineteenth and early twentieth centuries, flourishing music scenes in urban black communities and African Americans who achieved mainstream success and assimilation into white society. ${ }^{255}$ Yet there was still an invisible and defined line that kept these two cultural groups in their own world, particularly within middle and upper class white society. For financial success, prosperity and respect, white Americans did not need to live within black neighborhoods, conform to black standards of what was appropriate dress, how to speak, and with their cultural and social influence, were the ones who wrote the history books. In spite of movements such as racial uplift to improve the conditions of black life in American and integrate them into the dominant American culture, the racial and societal divisions remained and were applied to musical styles and genres. The simultaneously inclusion

${ }^{253}$ Sphinx Organization, http://www.sphinxmusic.org. [accessed March 26, 2015].

${ }^{254}$ Drewry and Doermann, Stand and Prosper, 18.

${ }^{255}$ Frederick Jerome Taylor, "Black Musicians in “The Philadelphia Tribune," 1912-20 in The Black Perspective in Music 18, no. 1/2 [1990], 127. Ellistine Perkins Holly, "Black Concert Music in Chicago, 1890 to the 1930s" in Black Music Research Journal 10, no. 1 [Spring 1990], 141, 143, 146. 
and exclusion of Clarence Cameron White during his lifetime was most likely due to ignorance and lack of awareness. Though he did perform and teach in multiracial settings, White was seen as part of the black American musical community rather than the American musical community. He performed and taught within a style that had not originated in black America, thus how could it represent black America? His sphere of influence was limited not because of his own personal lack of drive, talent and vision, but because society at large limited him since he did not fit the narrative of black American music that they were familiar with.

As DuBois wrote of "double consciousness" in The Souls of Black Folk, it is near to nigh impossible to view White's life solely through the lens of the black American experience. Throughout American history, black Americans have seen themselves through the lens of white America. Even White's rhetoric within The Southern Workman essay is not far removed from the mentality of white abolitionists' interpretation of spirituals in the 1850s. This information conjures many questions and concerns. Was White aware that his own perspective on jazz was reflective of the mainstream view of white music? Did he see his mindset as reflective of that? Does his view that the natural black voice was somehow untrained, comparing it to the "training" within the Western art music tradition take away his own mental and cultural autonomy?

These questions do not have easy answers. However, calling into doubt his position on classical music, jazz and other non-Western art music forms as indicative of racial and cultural indoctrination is only one side of the coin. Though such opinions are now recognized as culturally and racially biased, within White's time and cultural upbringing, Western art music was symbolic of the best humans could create, experience, and share through a musical style. $\mathrm{He}$ was espousing a perception that was rooted in his upbringing as a middle class black American man who grew up listening and playing Western art music. By all accounts, White did not allow 
the societal limitations constricting his exposure and recognition as a composer within the American concert music tradition to stop his involvement in teaching, performing and composing within that style. As we have seen with White's performances extending into the 1940s, he was dedicated to performing on an instrument and within a style that he loved and enjoyed. Despite the problematic nature of his belief in Western ethnocentric standards of musical maturity and refinement, it is clear that he did not see himself as conforming or assimilating. He was part of a musical style whose composers had created some of the most beautiful, inspiring, and uplifting music ever written and to see his career as simply an example of assimilation ignores the autonomy he had in deciding what he liked musically. 


\section{Chapter Four \\ To Be A Classical Violinist and Black: Western art music as a cultural and racial signifier}

In this final chapter, the discussion on Clarence Cameron White will turn to the uncomfortable, problematic questions posed at the very beginning of this paper. Instead of asking the basic question, "Was Clarence Cameron White black?" we need to ask the more layered, “What was Clarence Cameron White's idea of blackness?” He obviously saw himself as an African American man and was aware that he lived and worked in a racist society. Yet even the term "blackness" might have been too harsh, too political for him. As we shall see, being “black” or a "black American” was not simply defined by physical features. White's musical uplift ideology reflected perspectives and beliefs held by many middle and upper class blacks of the late nineteenth century, an ideology that was slowly being replaced in favor of the celebration and use of traditional African and African American artistic forms in the early twentieth century. ${ }^{256}$ Though some of his compositions did contain quotes of spirituals and non-Western harmonies and rhythms, they were used to "elevate" the material by showing its creative possibilities within a white European musical form and his opinions on non-Western musical styles reveal a ethnocentrism rooted in white American cultural standards.

Such a perspective was not new to the black community. In 1878, James Monroe Trotter's Music and Some Highly Musical People was published, the first comprehensive survey on black American music. ${ }^{257}$ Trotter wrote of over forty black musicians and musical groups within a social, historical and aesthetic context, even the first successful African American minstrel group, the Georgia Minstrels. ${ }^{258}$ Music and Some Highly Musical People

\footnotetext{
${ }^{256}$ Anderson, Deep River, 2-3.

${ }^{257}$ Schenbeck, Racial Uplift, 49. Floyd, The Power of Black Music, 103.

${ }^{258}$ Ibid.
} 
was written to showcase the best of the African American race, "to provide not mere musical knowledge to his readers, but rather social and human enlightenment." ${ }^{, 259}$ This was also reflected in Trotter's selection of musicians and musical groups to profile, often those trained or who performed in the Western art music tradition (minus the Georgia Minstrels). ${ }^{260}$ Trotter was active during a time when Western musical aesthetics were not the cultural norm but an example of "scientific music" - a term now used to describe the training of a musician to “produce 'correct' harmonies, refined melodies and more complex texture." ${ }^{261}$ Believed to have originated in American churches to improve the quality of congregational singing, the desire for "cultivated" music naturally spread to others areas of American musical society, perhaps best represented in the work of music critic John Sullivan Dwight, whose writings greatly contributed to the formulation of "high" and "low" music which placed Western art music and more vernacular styles within an oppositional binary. ${ }^{262}$

White's opinions on blues and jazz reflect that conflict, and as a result, place him, in a problematic position within black American history. Being black in America has functioned as a racial, social and political label throughout the nation's history. Support of social issues and political actions to improve the living situations of the black community became important markers in addition to artistic expressions that drew on African American culture and traditions. Despite his positive opinion of spirituals, was White less of a black man because his opinions on black musical idioms such as blues and jazz were cultural biased? To answer this question (or at least, attempt to answer it), we must understand the movement of musical, cultural and

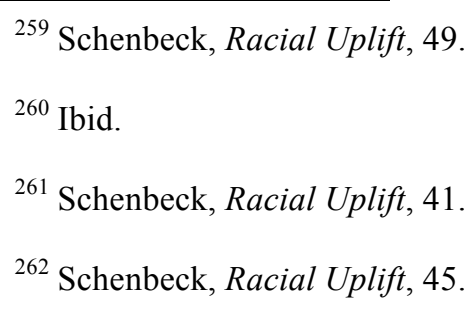


political shifts in the black American community within the twentieth century, as well as how the negative connotations of blues and jazz are part of a longer history of the aesthetics of African and African American music being described negatively through the writings of European and North American slavers, missionaries and travelers.

Katrina Dyonne Thompson's Ring Shout, Wheel About provides a fascinating look into the development of black musical stereotypes dating as far back as the fifth century BCE. ${ }^{263}$ The ethnocentrism within these writings also appear in the journals of European and North American visitors to the African continent dating from the fifteenth century. ${ }^{264}$ The intention of reducing religious traditions and musical practices to "strange traditions" and "unorganized" sounds would reinforce racial stereotypes and validate slavery's social function. ${ }^{265}$ The spread of travel journals in sixteenth century Europe, facilitated by the printing press and growth in a literate population, contributed to the spread of African musical and cultural stereotypes. ${ }^{266}$ One such example of the details of African musical cultures being brushed aside are some writers' observations of griots. For many West African societies, the griot served as musician, historian and advisor in addition to other responsibilities within his community. However, this complexity was completely lost if not disregarded by the foreign travelers that recorded their observations of music making within West African cultures. Griots were "importunate beggars" according to Andre Alvares de Almada in 1594, and nearly a hundred years later, Jean Barbot,

\footnotetext{
263 Thompson, Ring Shout, Wheel About, 16.

264 Thompson, Ring Shout, Wheel About, 17.

265 Thompson, Ring Shout, Wheel About, 7, 17.

266 Thompson, Ring Shout, Wheel About, 17.
} 
a slaver, wrote of a music performance that featured the "dances of the Filox," the latter term used to describe a pickpocket or "villain, thief, sharper.",267

The ethnocentrism in White's writing is perhaps most evident within "The Musical Genius of the American Negro." White uses the spiritual as a means of contrast and historical comparison with the successes in post-Civil War America and concert musicians of African descent extending back to the $18^{\text {th }}$ century. While using the creation and cultivation of the spirituals to show the determination of black Americans, White also presents the song as a naturalized part of black American musical practice:

Just what has the Negro contributed? We find his contribution in labor and also in Art. Running through all will be found his original and natural gift of song - everywhere a song and that song so unlike any other, so full of the human element that touches and grips and stays, that artist and layman alike respond to its thrill. Many have essayed to analyze the peculiar quality that gives the Negro music its extraordinary charm. ${ }^{268}$

White was not the only person to describe African Americans' vocal performances as emblematic of African American culture. The final chapter of The Souls of Black Folk, "The Sorrow Songs," contains Du Bois' exposure to this genre and presents a similar sentiment. "Ever since I was a child these songs have stirred me strangely. They came out of the South unknown to me, one by one, and yet at once I knew them of me and mine. ${ }^{, 269}$ But where White saw the spirituals as a point of growth towards the understanding and mastery of Western art music forms, Du Bois, saw the "sorrow songs" as a tool of cultural pride and inspiration for African

${ }^{267}$ Thompson, Ring Shout, Wheel About, 24. Isabelle Leymarie-Ortiz, "The Griots of Senegal and Change" in Africa: Rivista trimestrale di studi e documentazione dell'Lstituto italiano per l'Africa e l'Oriente 34, no. 3 [Sept 1979], 184-188.

\footnotetext{
${ }^{268}$ White, "The Musical Genius of the American Negro": 109.

${ }^{269}$ Du Bois, The Souls of Black Folk, 177.
} 
Americans and a soulful musical source for American society. ${ }^{270} \mathrm{Du}$ Bois wrote of the social and aesthetic value of the spirituals, spiritual singers from South Carolina and the Georgia Sea Islands and the contributions of the Fisk Jubilee Singers and through such an interpretation, Du Bois connected black American music to nationalist thinking, the only black intellectual of his time to do so. ${ }^{271} \mathrm{He}$ envisioned the creation of African-influenced American music, containing "elements both Negro and Caucasian" that would lead to recognition of the exchange and adaptation of musical traditions between whites and blacks. ${ }^{272}$ Rather than urging for this union of musical styles to "uplift" or "refine" black music, Du Bois aimed to show the contributions African Americans had made to American music. ${ }^{273}$ Black musical culture was not "passively imitative," but "original.,"274

Within other educational projects, White's adherence to African Americans' musical progression from spirituals to concert music is clearly articulated through his wording and selection of historical musical figures. In 1916, White wrote to several black musicians calling for a national organization of "Negro music teachers" to encourage "race unity and advancement. ${ }^{, 275}$ Though delayed for a few years, the National Association of Negro Musicians was established in 1919. White served as president of the organization from 1922-1924. ${ }^{276}$ In his speech at the fifth NANM convention, he outlined the goals and purpose of the organization in

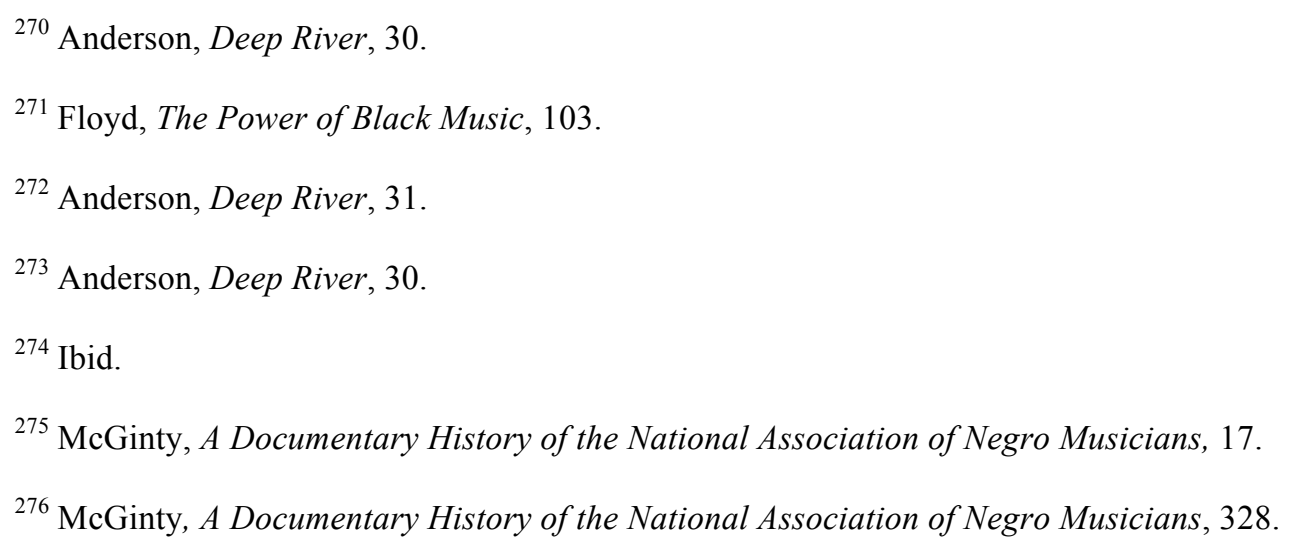


addition to listing various African Americans musicians and artisans. ${ }^{277} \mathrm{~A}$ format similar to his article in The Southern Workman, White grounds the organization's mission within historical and contemporary anecdotes, showing the talented musicians and artists within the black community. As recorded by Alice Carter Simmons, White spoke of three major goals of the NANM:

1) To spread abroad love and appreciation of Negro Music. 2) To foster a larger public appreciation for an education in good music. To develop higher education standards among Negro musicians and promote the exchange of ideas, and to promote the spirit of fellowship among all musicians. 3) To create wider opportunities for Negro artists and musicians and last but not least, to encourage and assist the cultivation of musical gifts among talented, deserving Negro youths, and such other activities as will extend the influence of music as a necessary and inspiring element in the life of our people. ${ }^{278}$

Though he does not specify "good music," it would be safe to assume that the context was Western art music, considering their educational mission was to "uphold art, to encourage a musical race that has already given to the world a Coleridge-Taylor, a Bridgetower....This is our musical background and who can say just how great our contribution to American art is to be?"279

White foresaw the African Americans' ideal musical contributions in the vein of Beethoven, Bach and Mozart, who mastered the forms of classical music before expanding and challenging their potential, resulting in some of the most beautiful, passionate and inspiring music ever composed. With the successful reception of Samuel Coleridge-Taylor, R. Nathanial Dett and other Western art music composers of African descent, how could the rest of America, the rest of the world, not notice?

\footnotetext{
${ }^{277}$ McGinty, A Documentary History of the National Association of Negro Musicians, 113-115.

278 McGinty, A Documentary History of the National Association of Negro Musicians, 114.

${ }^{279}$ McGinty, A Documentary History of the National Association of Negro Musicians, 115.
} 
Some noticed, but the music of black America that became their "great contribution" were not string quartets, piano concertos and oratorios. It was largely through blues, jazz, "race music"/rhythm and blues that African Americans would be recognized for their creative abilities and achieve mainstream success. There were black classical vocalists who achieved successful solo careers and joined major opera companies, but the contributions of black Americans to Western art music were not received with the same eagerness and excitement of styles considered by some blacks too close to the history and tradition of minstrelsy and disreputable performance locations. ${ }^{280}$ From an interview given in 1943, amongst his comments on the future of race relations and listing of his compositions and current projects, White shared his thoughts on jazz: "It lacks variety. Jazz stumbles on a good idea by accident, and then goes over it again and again." He also felt that the style lacked "technical knowledge of what it is doing." $" 281$ The hopes of White, Dett and other black musicians for black American concert music would be placed on the periphery of historical memory. The styles they had hoped to "elevate" through art song arrangement and integration into European classical music forms were embraced and consumed by the newest generation of young, white Americans in their contexts. ${ }^{282}$

White's negative opinion of jazz may come as surprising. But this presents another layer of complexity within the musical cultures of African Americans in segregated America. The assumption that African Americans across economic spectrums listened to the same music presents black America as a homogenous unity, which could not be further from the truth. William Grant Still, the "Dean of Afro American composers," also grew up listening to Western

${ }^{280}$ Southern, The Music of Black Americans, 332-333.

${ }^{281}$ Harold Meigs, "Noted Negro Musician Shows Faith That Masters Trouble: Dr. Clarence C. White Says Better Understanding of All Races to Come" Clarence Cameron White Collection, Box 14.

${ }^{282}$ Schenbeck, Racial Uplift, 131. 
art music and did not listen to the blues until his twenties. ${ }^{283}$ Though his "blues" era is the most well known in the public consciousness, I believe it is misleading to see it as an expression of his heritage. Though he was an African American, his cultural upbringing was different than an African American living in a rural, Southern community, where it would be very likely that he would hear if not play the blues. White's espousing of white American musical hierarchy was not just an expression of belief in Western cultural standards, but a reflection of his upbringing as a middle class African American. ${ }^{284}$ To view his standards as simply a symptom of the larger cultural problem does a disservice to the control he did have in viewing himself and his place within American society. Though White's and Still's cultural upbringing was not an uncommon part of the African American experience, it is still problematic when one considers that several of White's contemporaries who were educated in the American university system still challenged white American's understanding of black culture and musical idioms. In addition, the calls for racial and cultural pride within many black communities in the mid twentieth century created another issue for White's belief in Western musical standards remaining in the narrative of black American history.

The importance of an African American cultural identity as defined and crafted by other African Americans reached a peak in the late 1950s into the 1960s and ' 70 s, and opinions such as White's on elements of black music would become outdated and cultural offensive. White died in 1960, the start of a decade defined by significant social change in the United States with the passage of non-discriminatory legislation. ${ }^{285}$ Social and political activity and calls for racial

${ }^{283}$ Gatewood, "The Formative Years of William Grant Still,” 35.

${ }^{284}$ Schenbeck, Racial Uplift, 47.

285 "The Voting Rights Act” from The United States Department of Justice http://www.justice.gov/crt/about/vot/intro/intro b.php (accessed March 22, 2015). 
solidarity had been present within the black community since the nineteenth century, but it was through the Civil Rights movement of the 1950s and 1960s that the greatest amount of societal change occurred thanks to civil rights groups' demonstrations and lobbying of state and federal officials. ${ }^{286}$ Despite these achievements, racial equality was far from a reality. The ideological approaches of southern desegregation groups such as Dr. King's were viewed by some as inadequate in addressing the structural issues that had allowed racism to flourish. ${ }^{287}$ The emerging militancy in black social organizations such as SNCC (Student Nonviolent Coordinating Committee) and the creation of various black militancy groups such as the Black Panther Party called for black self-determination and critiqued liberal integration. ${ }^{288}$ Articulations of anger over centuries of persecution, denial of basic rights and the resulting skewed balance of power in the political and economic sphere contributed to the rhetoric of selfdetermination including little to no reliance on mainstream, white America. ${ }^{289}$ Amongst this emerging rhetoric of black self-love and determination, though in no means a unified ideological movement, White's Western art music standards had no place within the new zeitgeist. ${ }^{290}$ Despite his contributions to musical education in African American communities, his support of

${ }^{286}$ Charles V. Hamilton, "Federal Law and the Courts in the Civil Rights Movement" in The Civil Rights Movement in America, Charles W. Eagles, ed., [Jackson: University Press of Mississippi, 1986], 97-98.

${ }^{287}$ Cedric Johnson, Revolutionaries To Race Leaders: Black Power and the Making of African American Politics [Minneapolis: The University of Minnesota Press, 2007], xxiv.

${ }^{288}$ Johnson, Revolutionaries to Race Leaders, xx-xxi.

${ }^{289}$ Peniel E. Joseph, "Historians and the Black Power Movement" in OAH Magazine of History 22, no. 3 [July 2008], 9-10.

${ }^{290}$ James Smethurst, The Black Arts Movement: Literary Nationalism in the 1960s and 1970s [Chapel Hill: The University of North Carolina Press, 2005], 57-58. 
white American ideals of musical beauty and aesthetic were detrimental to the emerging Black power movement.

While such a shift is understandable, it also contributed to the lost of a variety of experiences that have been and continue to be part of the black American musical experience. I do not mean to say that White's musical ethnocentrism should be excused. Instead, its inclusion will showcase the diversity of cultural standards within black American history, learning and understanding the stories of those who saw the need to accept and live by white American cultural standards and those of African Americans who believed and encouraged autonomous expressions of black culture.

Du Bois' vision of African-influenced American music became a reality in the twentieth century. The embracement of black music by the dominant American culture resulted in the creation of rock n' roll, "blue-eyed" soul and stylistic elements with origins in the black community. Radano's Lying Up A Nation includes a portion of an essay by Ralph Ellison, author of "Invisible Man," that shows how interwoven American cultural expressions were in spite of the with the racial divisions:

The problem here is that few Americans know who and what they really are. That is why few of these groups - or at least few of the children of these groups - have been able to resist the movies, television, baseball, jazz, football, drum-majoretting, rock, comic strips, radio commercials, soap operas, book clubs, slang, or any of a thousand other expressions and carriers of our pluralistic and easily available popular culture. And it is here precisely that ethnic resistance is least effective. On this level the melting pot did indeed melt, creating such deceptive metamorphoses and blending of identities, values, and life-styles that most Americans whites are culturally part Negro American without even realizing it. $^{291}$

The inclusion of black music within white society has been much more common than the inverse. As noted before, the interests and opinions of those within the dominant American culture

291 Radano, Lying Up A Nation, 288-289. 
greatly influenced how black music was received and which black musical styles were performed before white audiences. Black classical instrumentalists and art music composers did not experience such an inclusion. The majority of African American classical instrumentalists were active within the black communities and despite those such as White who straddled both racial spheres, the Western art music community's sense of cultural and in turn racial superiority largely contributed to the exclusion of African Americans from major ensembles.

White's musical ethnocentrism was a reflection of the society and culture he lived in and influenced, directly or indirectly, his set of musical standards and aesthetics. His low opinion of jazz, a musical style rooted in black American culture, was a perspective interpreted by other African Americans as a cultural betrayal. ${ }^{292}$ But he did not shy away from using African American folk idioms, spirituals and other traditional music within his compositions. From his Bandana Sketches which contained four movements inspired by spirituals to his opera, Ouanga!, White continuously proved that these "opposing" musical styles could be used in Western art music forms. By programing his own compositions with Samuel Coleridge-Taylor's and arrangements of spirituals, White was continuously contributing to the spread of black concert music throughout his performing career. While he did believe in the cultural superiority and refinement of art music, he also believed that spirituals and other traditional black music had a place within the sphere of Western art music culture. These contradictions residing simultaneously within one man's mind, life, and career is an embodiment of the contradictions that have existed and continue to exist within American society. It is irresponsible to simplify the complexity of White's life, America and black Americans to the "us" versus "them" mentality

${ }^{292}$ LeRoi Jones (Amiri Baraka), Blues People: Negro Music in White America [New York: Harper Perennial, 1963], 57-59. 
that is one part of the story of race relations in this country. Doing so ignores the complexity of the history of a people who recreated their culture in over three hundred years of slavery and over a hundred years of disenfranchisement and discrimination. Through assimilation, integration and self-determination, African Americans developed and believed in different ways to achieve the same goal: equality and equity between whites and blacks.

White's belief in Western art music as uplift and his dedication to education, particularly within the black community, shows that his love of music and its social function was an integral part of his professional and personal identity. Though not without his contradictions, White intended to use his musical career to improve the quality of African American lives. He recognized and accepted the importance of sharing with black students of Western art music his love of this style and the repertoire written by those of African descent. Without a doubt, he was dedicated to educating the next generation of African American classical musicians and spreading the music of black classical composers. 


\section{Conclusion}

These chapters have led us through Clarence Cameron White's study of classical violin, the formulation of his performing career, aspects of his violin pedagogy and how he and other black concert musicians navigated the racial limitations placed on them by American society. His views of music through a Western ethnocentric lens is problematic: he lived in a time when African Americans and other non-white minorities were systematically repressed, abused and in some cases outright killed for entertainment. That he believed in Western art music's cultural superiority, a mindset that was part of an ethnocentrism that condoned such foul and inhuman behavior, makes his narrative less than perfect.

Despite this issue being apparent to us modern readers, aware of the need for cultural relativism if so many people of differing appearances, cultures and religions are to respect and understand each other, it is important to remember that in White's mind, his view of Western art music as "the music" and its function within American society and African American society was not a betrayal of the race. Despite all-too popular assumptions, African American culture and Western art music culture are not separate entities. From the writings and opinions of White's that have been discussed and analyzed, it seem he was fully aware of that as well.

In spite of societal pressure to conform to white American standards, White decided he wanted to play classical violin, teach classical violin and compose classical music because that was the music he grew up with and that he loved. With the dual function so many actions of African Americans had during the period of uplift ideology, it is hard not to wonder if all actions by its members were not done without a larger social aim in mind. There were those whose lives were focused on improving the quality and equity of African Americans and White was one of them. But to see his entire life and career as a societal tool to improve the lives of his people is to 
remove his humanity. We will never know the real Clarence Cameron White: all we have are photos, letters, recital programs, reviews, recordings and articles that provide a glimpse into what he thought, who he interacted with, what he loved, disliked and misunderstood. That these items remain and so much material on his life is still largely untouched shows that much more needs to be done in terms of researching, discussing and including black classical violinists and in turn, black classical string players within the history of Western art music and African American music.

The lack of minorities and women within the narrative of Western art music has been discussed, debated, and addressed. It is not uncommon to see William Grant Still discussed in the same textbook as Johann Sebastian Bach. ${ }^{293}$ Yet there is still much more that needs to be done. In addition to expanding the amount of topics researched on areas within black classical string music and performance, the amount of music by black composers must be further integrated into the repertoire of stringed instruments and orchestral ensembles. Though performers such as Rachel Barton Pine, Philippe Graffin and other instrumentalists past and present have recorded and performing violin works by black composers, there is still much more that needs to be done and can be done for this area of Western art music history to be more prevalent in the minds of scholars, teachers and students. ${ }^{294}$ This is a project that requires decades, if not centuries to see fulfilled and needs many other interested and eager scholars and students to question, investigate and expose the variety of cultures and ethnicities that have been a part of Western art music and

${ }^{293}$ Lucius R. Wyatt, "The Inclusion of Concert Music of African-American Composers in Music History Courses". J. Peter Burkholder, Donald Jay Grout, Claude V. Palisca, ed. A History of Western Music, $8^{\text {th }}$ edition [New York: W. W. Norton \& Company 2010], 895, 902-903.

${ }^{294}$ Lucius R. Wyatt, “The Present State and Future Needs of Research in Black Concert and Recital Music" in Black Music Research Journal 1 [1980]: 80-94. 
classical violin history. It is a disservice to both areas and to the students of each to present half the story. It is true that the inquisitive student will investigate on their own, but the diversity and variety of people within this musical form should not be secondary information. 


\section{BIBLIOGRAPHY}

\section{ARCHIVES}

Clarence Cameron White Collection 1872-1965, Moorland-Spingarn Research Center, Howard University.

\section{ARTICLES \& RECORDINGS}

Allen, William Duncan. "Correspondence" in The Black Perspective in Music, Vol. 11, No. 1 (Spring 1983).

Banat, Gabriel. "Le Chevalier de Saint-Georges, Man of Music and Gentleman-At-Arms: The Life and Times of An Eighteenth-Century Prodigy" in Black Music Research Journal Vol.10, No. 2 (Autumn 1990): 177-212.

Baron, John H. "Vieuxtemps (and Ole Bull) in New Orleans" in American Music, Vol. 8, No. 2 (Summer 1990): 210-226.

Bonilla-Silva, Eduardo. "The Invisible Weight of Whiteness: The Racial Grammar of Everyday Life in Contemporary America" in Ethnic \& Racial Studies, Vol. 35, No. 2 (Feb 2012): 173-194.

Brearley, John. "The Segankuru - A "Bush Fiddle" or a Bowed Bow?: Some of its Exponents and Their Songs" in Botswana Notes and Records, Vol. 28 (1996): 121-144.

Carver, Marva. "Removing the "Minstrel Mask" in the Musicals of Will Marion Cook" in The Musical Quarterly, Vol. 84, No. 2 (Summer 2000): 206-220.

Clague, Mark. "From Commodity to Creator: The Search For Social Equality Through Cultural Virtuosity" in Violin Concertos by Black Composers of the $18^{\text {th }}$ and $19^{\text {th }}$ Centuries, Cedille Records CDR 900000351997. 
Coleridge-Taylor, Samuel. Coleridge-Taylor, Dvoŕák: Violin Concertos, Phillipe Graffin, The Johannesburg Philharmonic Orchestra, Avie Records AV0044, 2004.

Cumming, Ashley, "The Birth of the US Orchestral Audition" in Horn Call: Journal of the International Horn Society, Vol. 45, No. 2 (Feb 2015): 49-52.

Dargie, Dave. "Umakhweyane": A Musical Bow and Its Contribution to Zulu Music" in African Music, Vol. 8, No. 1 (2007): 60-81.

Dontsa, Luvuyo. "The Tonalities of the Isankuni” in The Galpin Society Journal, Vol. 60 (April 2007): 161-166.

Edwards, Vernon H. and Michael L. Mark. "In Retrospect: Clarence Cameron White" in The Black Perspective in Music, Vol. 9, No. 1 (Spring 1981): 51-72.

Flandreau, Suzanne. "Black Music in the Academy: The Center for Black Music Research" in Notes, Vol. 55, No. 1 (Sep 1998): 26-36.

Folmsbee, Stanley J. "The Origin of the First "Jim Crow" Law" in The Journal of Southern History, Vol. 15, No. 2 (May 1949): 235-247.

Foster, Melvin Fowler. “The African-American Operatic Tenor: Coping with Discrimination” in Journal of Singing: the Official Journal of the National Association of Teachers of Singing, Vol. 58, No. 3 [Jan-Feb 2002]: 203-214.

Henderson, Alexa Benson. "Heman E. Perry and Black Enterprise in Atlanta, 1908-1925" in The Business History Review 61, no. 2 (Summer, 1987): 216-242.

Holly, Ellistine Perkins. "Black Concert Music in Chicago, 1890 to the 1930s" in Black Music Research Journal, Vol. 10, No. 1 (Spring 1990): 141-149.

Holmes, Dwight O. W. "Fifty Years of Howard University: Part II" in The Journal of Negro History, Vol. 3, No. 4 (Oct 1918): 368-380. 
Hudson, J. Blaine. "Simple Justice: Affirmative Action and American Racism in Historical Perspective" in The Black Scholar, Vol. 25, No. 3 (Summer 1995): 16-23.

Joseph, Peniel E. "Historians and the Black Power Movement" in OAH Magazine of History, Vol. 22, No. 3 (July 2008): 8-15.

Karpf, Juanita "For Their Musical Uplift: Emma Azalia Hackley and Voice Culture in African American Communities" in International Journal of Community Music, Vol. 4, No. 3 (2011): 237-256.

Knapik, Stefan. "Vitalistic Discourses of Violin Pedagogy in the Early Twentieth Century" in $19^{\text {th }}$ Century Music, Vol. 38, No. 2 (Fall 2014): 169-190.

Kupferstein, Kyla. "Young Eight to Black Youth: There are Classical Musicians Who Look Like You" in The New York Amsterdam News (June 16, 2005): 37-3.

Lerma, Dominique-René de. "The Chevalier de Saint-Georges" in The Black Perspective in Music, Vol. 4, No. 1 (Spring 1976): 3-21. . "Black Composers in Europe: A Works List" in Black Music Research Journal, Vol. 10, No. 2 (Autumn 1990): 275-334.

Leymarie-Oritz, Isabelle. "The Griots of Senegal and Change" in Africa: Rivista trimestrale di studi e documentazione dell'Lstituto italiano per l'Africa e l'Oriente, Vol. 34, No. 3 (Sept 1979): 184-197.

McCabe, Janice. "Racial and Gender Microaggressions on A Predominantly-White Campus: Experience of Black, Latina/o and White Undergraduates" in Race, Gender \& Class, Vol. 16, No. 1/2 (2009): 133-151.

McGinty, Doris Evans. "That You've Come So Far To See Us": Coleridge-Taylor in American" in Black Music Research Journal, Vol. 21, No. 2 (Autumn 2001): 197-234. 
. "The Washington Conservatory of Music and School of Expression" in The Black

Perspective in Music, Vol. 7, No. 1 (Spring 1979): 59-74.

Mundy, Rachel. "Musical Evolution and the Making of Hierarchy" in The World of Music, Vol. 48, No. 2 (2006): 13-27.

Patterson, Willis. "The African-American Art Song: A Musical Means for Special Teaching and Learning” in Black Music Research Journal, Vol. 16, No. 2 (Autumn 1996): 303-310.

Prchal, Martin. "The Man Behind the Exercises" in The Strad, Vol. 109, No. 1301 (Sep. 1998): 942-945.

Raff, Joachim. Encores, Itzhak Perlman \& Samuel Sanders, EMI Classics 7243562596 21, 2003.

Ramsey Jr., Guthrie. “The Pot Liquor Principle: Developing A Black Music Criticism in American Music Studies" in American Music, Vol. 22, No. 2 (Summer 2004): 284-295. . "Who Hears Here? Black Music, Critical Bias, and the Musicological Skin Trade" in The Musical Quarterly, Vol. 85, No. 1 (Spring 2001): 1-52.

Schmalenberger, Sarah. "Shaping Uplift Through Music" in Black Music Research Journal, Vol. 28, No. 2 (Fall 2008): 57-83.

Sears, Ann. "A Certain Strangeness": Harry T. Burleigh's Art Songs and Spiritual Arrangements" in Black Music Research Journal, Vol. 24, No. 2 (Autumn 2004): 227-249.

Sullivan, Lester. "Composers of Color of Nineteenth-Century New Orleans: The History Behind the Music" in Black Music Research Journal, Vol. 8, No. 1 (1988): 51-82.

Taylor, Frederick Jerome. "In Retrospect: Black Musicians in "The Philadelphia Tribune”, 191220" in The Black Perspective in Music, Vol. 18. No.1/2 (1990): 127-140. 
Titcomb, Caldwell. "Black String Musicians: Ascending the Scale" in Black Music Research Journal, Vol. 10, No. 1(Spring 1990): 107-112.

Wells, Paul. "Fiddling As An Avenue of Black-White Musical Interchange" in Black Music Research Journal Vol. 23, No. 1/2 (Spring-Autumn 2003): 135-147.

White, Clarence Cameron. The Negro Music Journal, Vol. I, No. 1, 4-12 (Sep 1902, Dec $1902-$ Aug 1903): 2-3, 59-60, 76-79, 107-110, 127-129, 153-155, 177-178, 205-206, 229-230, 253-254. . The Negro Music Journal, Vol. II, No. 13-15 (Sep-Nov 1903): 17-18, 44-45, 69-70. ."The Musical Genius of the American Negro" in The Southern Workman, Vol. 62, No. 3 (March 1933): 108-118.

. "Lament" from Bandana Sketches in Lost Sounds: Blacks and the Birth of the Recording Industry 1891-1922, Clarence Cameron White, Archeophone Records 1005, 2005. . Levee Dance, op. 27, no. 2 in It Ain't Necessarily So: Legendary Classic and Jazz Studio Takes, Jascha Heifetz, Deutsche Grammophon B0007190-02, 2006.

Wolfe, Charles. "Rural Black String Band Music" in Black Music Journal, Vol. 10, No. 1 (Spring 1990): 32-35.

Wright, Josephine. "Violinist José White in Paris, 1855-1875" in Black Music Research Journal, Vol. 10, No. 2 (Autumn 1990): 213-232.

Wyatt, Lucius R. “The Present State and Future Needs of Research in Black Concert and Recital Music" in Black Music Research Journal, Vol. 1 [1980]: 80-94. . "Six Composers of Nineteenth-Century New Orleans" in Black Music Research Journal, Vol. 10, No. 1 (Spring, 1990): 125-140. 
. "The Inclusion of Concert Music of African-American Composers in Music History Courses" in Black Music Research Journal, Vol. 16, No. 2 (Autumn 1996): 239-257. Yancy, George and Noam Chomsky, "Noam Chomsky on the Roots of American Racism" in The New York Times (March 18, 2015) (accessed April 1, 2015).

"The Black-White Divide in Cultural Pursuits" in The Journal of Blacks in Higher Education, No. 58 (Winter, 2007/2008): 13-15.

\section{BOOKS \& ENCYCLOPEDIC ENTRIES}

Anderson, Paul Allen. Deep River: Music and Memory in Harlem Renaissance Thought. Durham: Duke University Press, 2001.

Auer, Leopold, Violin Playing As I Teach It. London: Gerald Duckworth \& Co. Ltd., 1960. Axelrod, Dr. Herbert R., ed. Heifetz. Neptune City, N.J.: Paganiniana Publications, Inc., 1976, 1981, 1990.

Baker Jr., Houston. Modernism and the Harlem Renaissance. Chicago: University of Chicago Press, 1989.

Barlow, Bill. "Minstrelsy" in The New Encyclopedia of Southern Culture, ed. Samuel S. Hill. Chapel Hill: University of North Carolina Press 2014, 89-90.

Baptist, Edward E. The Half Has Never Been Told: Slavery and the Making of American Capitalism. New York: Basic Books, 2014.

Bennett, Dawn Elizabeth. Understanding The Classical Music Profession: The Past, The Present and Strategies For The Future. Aldershot: Ashgate, 2008.

Brooks, Tim. Lost Sounds: Blacks and the Birth of the Recording Industry 1890-1919. Urbana: University of Illinois Press, 2004. 
Bryan, Karen M. “Clarence Cameron White’s Ouanga! In The World of The Harlem

Renaissance" in Blackness in Opera, ed. Naomi André, Karen M. Bryan, and Eric Saylor. Urbana: University of Illinois Press, 2012, 116-140.

Burkholder, J. Peter, Donald Jay Grout, Claude V. Palisca, ed. A History of Western Music, $8^{\text {th }}$ edition. New York: W. W. Norton \& Company, 2010.

Carter, Marva Griffin. Swing Along. The Musical Life of Will Marion Cook. New York: Oxford University Press, 2008.

Cataliotti, Robert H. “African American Music in Chicago During the Chicago Renaissance” in Writers of the Black Chicago Renaissance, ed. Steven C. Tracy. Urbana: University of Illinoi Press, 2011.

Drewry, Henry N. and Humphrey Doermann. Stand and Prosper: Private Black Colleges and Their Students. Princeton: Princeton University Press, 2012.

Du Bois, W. E. B. The Souls of Black Folk. New York: Barnes and Noble Books, 2003.

Epps, Garrett. Democracy Reborn: The Fourteenth Amendment and the Fight for Equal Rights in Post-Civil War America. New York: Henry Holt and Company, LLC, 2006.

Epstein, Dena J. Sinful Tunes and Spirituals: Black Folk Music To The Civil War. Urbana: University of Illinois Press, 1977, 2003.

Floyd, Jr. Samuel A, ed. Black Music in the Harlem Renaissance: A Collection of Essays. Westport: Greenwood Publishing, 1990. . The Power of Black Music: Interpreting Its History From Africa to the United States. New York: Oxford University Press, 1995.

Ford, Robert, ed. A Blues Bibliography: The International Literature of an Afro-American Music Genre, $2^{\text {nd }}$ Edition. New York: Routledge, 2007. 
Frederickson, George M. The Black Image in the White Mind: The Debate on Afro-American Character and Destiny, 1817-1914. New York: Harper \& Row, Publishers, 1971.

Gatewood, Willard B. "The Formative Years of William Grant Still: Little Rock, Arkansas, 1895-1911” in William Grant Still, ed. Catherine Parsons Smith. Urbana: University of Illinois Press, 2008, 21-38.

Hamilton, Charles V. "Federal Law and the Courts in the Civil Rights Movement" in The Civil Rights Movement in America, ed. Charles W. Eagles. Jackson: University Press of Mississippi, 1986, 97-126.

Haskins, James Haskins. Black Music in America: A History Through Its People. Thomas Y. Crowell Company, 1987.

Hochstat-Greenberg, Janice Leslie, ed. Jazz Books in the 1990s: An Annotated Bibliography. Lanham: Scarecrow Press, 2010.

Horowitz, Joseph, "Dvoŕák and the New World: A Concentrated Moment" in Dvoŕák and His World, ed., Michael Beckerman. Princeton: Princeton University Press, 2012, 92-103. Jarrett, Gene Andrew. Representing the Race: A New Political History of African American Literature. New York: New York University Press, 2011.

Johnson, Cedric. Revolutionaries To Race Leaders: Black Power and the Making of African American Politics. Minneapolis: The University of Minnesota Press, 2007.

Jones, Leroi (Amiri Baraka). Blues People: Negro Music in White America. New York: Harper Perennial, 1963.

Kernodle, Tammy L. "Having Her Way: The Blues As The Black Woman’s Lament" in Women's Voices Across Musical Worlds. Boston: Northeastern University, 2004, 213229. 
Locke, Alain, ed. The New Negro: Voices of the Harlem Renaissance. New York: Touchstone, 1997.

McGinty, Doris Evans, ed. A Documentary History of the National Association of Negro Musicians. Chicago: Columbia College, 2004.

Philip, Robert. Performing Music in the Age of Recording. New Haven: Yale University Press, 2004.

Radano, Ronald. Lying up a Nation: Race and Black Music. Chicago: University of Chicago Press, 2003.

Roth, Henry. Violin Virtuosos: From Paganini to the $21^{\text {st }}$ Century. Los Angeles: Carolina Classics Books, 1997.

Schenbeck, Lawrence. Racial Uplift and American Music, 1878-1943. Jackson: University of Mississippi, 2012.

Smethurst, James. The Black Arts Movement: Literary Nationalism in the 1960s and 1970s. Chapel Hill: The University of North Carolina Press, 2005.

Southern, Eileen. The Music of Black Americans: A History, $3^{\text {rd }}$ edition. New York: W. W. Norton \& Company, 1997.

Thompson, Katrina Dyonne. Ring Shout, Wheel About: The Racial Politics of Music and Dacne in North American Slavery. Urbana: University of Illinois Press, 2014.

Von Arx, Victoria. "White, Clarence Cameron” in The International Dictionary of Black Composers, Vol. 2, Samuel Floyd Jr., ed. Chicago: Fitzroy Dearborn Publishers, 1999, 1199-1206. 
White, Clarence Cameron. "The Musical Genius of the American Negro" in Jazz in Print: An Anthology of Selected Early Readings in Jazz History. Hillsdale: Pendragon Press 2002, 309-313.

\section{DISSERTATIONS}

Christian, Amelia. Ševčik's Analytics of Works By Mendelssohn and Bazzini: A Pedagogical Analysis. City University of New York, 2013.

\section{ELECTRONIC RESOURCES \& SCORES}

Coleridge-Taylor, Samuel. "Ballade in C Minor, Op. 73” Sibley Music Library, Eastman School of Music.

https://urresearch.rochester.edu/institutionalPublicationPublicView.action?institutionalIte $\underline{m I d=16330}$. (accessed February 7, 2015)

Garden, Edward. "Anton Rubinstein” in Grove Music Online.

http://www.oxfordmusiconline.com.www.libproxy.wvu.edu/subscriber/article/grove/music $124053 ? q=$ Anton + Rubinstein $\&$ search $=q u i c k \& p o s=1 \&$ start $=1 \#$ firsthit. . (accessed March 28, 2015)

Marschner, Bo and Finn Egeland Hansen. "Niels Gade" in Grove Music Online. http://www.oxfordmusiconline.com.www.libproxy.wvu.edu/subscriber/article/grove/musi

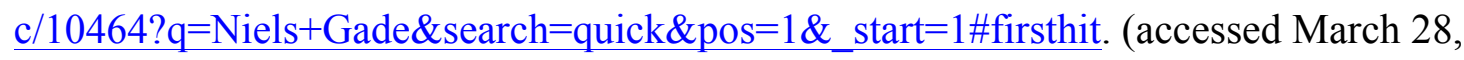
2015)

Raff Joachim.“6 Morceaux, Op. 85,” IMSLP. http://imslp.org/wiki/6_Morceaux,Op.85_(Raff,_Joachim) (accessed April 22, 2015) 
Vega, Aurelio de la, "José Lafitte White" in Grove Music Online http://www.oxfordmusiconline.com.www.libproxy.wvu.edu/subscriber/article/grove/musi

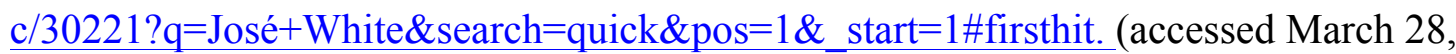
2015)

"Prominent Musician Makes Extended Tour" in The Oberlin Review, Vol. 51, No. 38, Oberlin College Archives http://dcollections.oberlin.edu/cdm/ref/collection/p15963coll9/id/174347. (accessed March 24, 2015)

Sphinx Organization. http://sphinxmusic.org. (accessed March 30, 2015).

"The Voting Rights Act” from The United States Department of Justice http://www.justice.gov/crt/about/vot/intro/intro_b.php (accessed March 22, 2015)

Barber, Barbara. Solos for Young Violinists, Vol. 4. Miami: Summy-Birchard Inc., 1997, 22-24. 